\title{
Five blind men and the elephant: what can the NASA Aura ozone measurements tell us about stratosphere-troposphere exchange?
}

\author{
Q. Tang ${ }^{1,2}$ and M. J. Prather ${ }^{1}$ \\ ${ }^{1}$ Department of Earth System Science, University of California, Irvine, California, 92697, USA \\ ${ }^{2}$ Department of Biological and Environmental Engineering, Cornell University, Ithaca, New York, 14853, USA \\ Correspondence to: Q. Tang (qtang@ cornell.edu)
}

Received: 17 September 2011 - Published in Atmos. Chem. Phys. Discuss.: 29 September 2011

Revised: 10 January 2012 - Accepted: 19 January 2012 - Published: 2 March 2012

\begin{abstract}
We examine whether the individual ozone $\left(\mathrm{O}_{3}\right)$ measurements from the four Aura instruments can quantify the stratosphere-troposphere exchange (STE) flux of $\mathrm{O}_{3}$, an important term of the tropospheric $\mathrm{O}_{3}$ budget. The level 2 (L2) Aura swath data and the nearly coincident ozone sondes for the years 2005-2006 are compared with the 4-D, high-resolution $\left(1^{\circ} \times 1^{\circ} \times 40\right.$-layer $\left.\times 0.5 \mathrm{~h}\right)$ model simulation of atmospheric ozone for the same period from the University of California, Irvine chemistry transport model (CTM). The CTM becomes a transfer standard for comparing individual profiles from these five, not-quite-coincident measurements of atmospheric ozone. Even with obvious model discrepancies identified here, the CTM can readily quantify instrument-instrument biases in the tropical upper troposphere and mid-latitude lower stratosphere. In terms of STE processes, all four Aura datasets have some skill in identifying stratosphere-troposphere folds, and we find several cases where both model and measurements see evidence of high- $\mathrm{O}_{3}$ stratospheric air entering the troposphere. In many cases identified in the model, however, the individual Aura profile retrievals in the upper troposphere and lower stratosphere show too much noise, as expected from their low sensitivity and coarse vertical resolution at and below the tropopause. These model-measurement comparisons of individual profiles do provide some level of confidence in the model-derived $\mathrm{STE}_{3}$ flux, but it will be difficult to integrate this flux from the satellite data alone.
\end{abstract}

\section{Introduction}

Quantifying and understanding the causes of changes in the tropospheric ozone $\left(\mathrm{O}_{3}\right)$ burden are important topics for climate research and environmental studies, as ozone is a major greenhouse gas and plays a key role in the tropospheric chemistry. Besides obvious factors such as anthropogenic emissions of ozone precursors (Gauss et al., 2006; Hoor et al., 2009; Myhre et al., 2011; Holmes et al., 2011) and natural emissions of biogenic volatile organic compounds (Atkinson and Arey, 2003; Shao et al., 2009), stratospheric ozone influx has been identified as a major driver of tropospheric ozone changes (Roelofs and Lelieveld, 1997; Fusco and Logan, 2003; Terao et al., 2008; Hsu and Prather, 2009). There are large uncertainties in the estimates of global annual stratosphere-troposphere exchange (STE) of ozone flux either derived from observations (450 $\mathrm{Tg}\left(\mathrm{O}_{3}\right) \mathrm{yr}^{-1}$ (range, 200-870) (Murphy and Fahey, 1994), $510 \mathrm{Tg}\left(\mathrm{O}_{3}\right) \mathrm{yr}^{-1}$ (450-590) (Gettelman et al., 1997), $550 \pm 140 \mathrm{Tg}\left(\mathrm{O}_{3}\right) \mathrm{yr}^{-1}$ (Olsen et al., 2001)) or from model simulations (e.g., Denman et al., 2007, Table 7.9 and references therein). There are also disagreements in terms of the magnitude and phase of the annual cycle as well as the geographical patterns (Gettelman et al., 1997; Roelofs and Lelieveld, 1997; Olsen et al., 2004; Hsu et al., 2005; Hsu and Prather, 2009). The large uncertainties and differences in the assessments of the STE $\mathrm{O}_{3}$ budget are partly due to the different definitions and diagnostic methods used in these studies and partly due to the great temporal and spatial variances of the STE flux.

The four Earth Observing System (EOS) Aura satellite ozone measurements (High Resolution Dynamics Limb Sounder (HIRDLS), Microwave Limb Sounder (MLS), Ozone Monitoring Instrument (OMI), and Tropospheric Emission Spectrometer (TES)) plus the coincident ozone sondes flown for calibration/validation of the satellite instruments comprise a somewhat overlapping set of five different ozone measurements. We merge these five with the 
University of California, Irvine (UCI) chemistry transport model (CTM) simulations with the overall goal of using the model and measurements to derive a better understanding of how the stratospheric source affects the tropospheric ozone abundance. We evaluate if the Aura ozone measurements can provide useful information regarding processes, such as tropopause folds (TFs) (Danielsen, 1968), relate these events to $\mathrm{STE}_{3}$ fluxes; and examine the consistency amongst different Aura datasets, particularly in the upper troposphere and lower stratosphere (UT/LS) region $(300-100 \mathrm{hPa})$. The $\mathrm{UT} / \mathrm{LS}$ is where the influx of stratospheric $\mathrm{O}_{3}$ is most evident (Terao et al., 2008) and where $\mathrm{O}_{3}$ has the largest impact on radiative forcing of climate (Lacis et al., 1990). Identifying STE events, such as stratosphere-troposphere folds, is inherently a very difficult task for space remote sensing, especially for nadir-viewing instruments, and is beyond the designed scope of Aura (except for a fully functional HIRDLS). Therefore, we draw on the parable of the five blind men and the elephant, where the five Aura measurements are the five "blind men" who are touching the "elephant" (ozone) in different places (i.e., using different remote sensing techniques and observing different parts of the atmosphere (OMI and TES have some overlap)). The UCI CTM is able to see the whole "elephant" and thus provides an intercomparison platform and integrator to connect and relate the different Aura ozone measurements.

\section{Chemistry transport model}

The chemistry transport model (CTM) is forced by the pieced-forecast meteorological fields provided by University of Oslo (Kraabøl et al., 2002; Isaksen et al., 2005) from the European Centre for Medium-Range Weather Forecasts (ECMWF) Integrated Forecast System (IFS). The model is initialized on 1 January 2005 (00:00 UTC) with a restart file from a CTM simulation ending 31 December 2004 at a resolution of T42 $\left(\sim 2.8^{\circ} \times \sim 2.8^{\circ}\right)$ with 40 layers and then run through 31 December 2006 at $1^{\circ} \times 1^{\circ} \times 40$-layer $\times 0.5 \mathrm{~h}$ resolution. The $1^{\circ} \times 1^{\circ}$ meteorological fields are only available for two years (2005-2006). The modeled atmosphere extends from the surface to $2 \mathrm{hPa}$ with $\sim 1 \mathrm{~km}$ vertical resolution around the tropopause. Because the interpolation from the T42 grid to the $1^{\circ} \times 1^{\circ}$ grid introduces errors at the beginning of the $1^{\circ} \times 1^{\circ}$ simulation, the quantitative analysis here often omits the first few months. The primary model output for this analysis is a 65 -min swath along the Aura orbit every half an hour (30 min backward and $35 \mathrm{~min}$ forward from the sampling point) so that we can interpolate the overlapped swaths to match the exact time and location of each Aura measurement. The additional 5-min forward swath is designed to cover the MLS observations scanning in the forward limb direction. The swath is wide enough to include the cross-track scan of OMI and the off-track viewing geometry of HIRDLS, which is outside the OMI swath. We also store $65^{\circ} \mathrm{S}-65^{\circ} \mathrm{N} \mathrm{O}_{3}$ field every two hours to match sondes.

The UCI CTM simulates a basic tropospheric chemistry, including most of the major mechanisms, with the ASAD (A Self-contained Atmospheric chemistry coDe) software package (Carver et al., 1997) and a simplified stratospheric $\mathrm{O}_{3}$ chemistry with Linoz version 2 (Hsu and Prather, 2009). The ASAD package includes the updates for the chemistry solver (Tang and Prather, 2010) and the chemical kinetics and photochemical coefficients (Sander et al., 2006). The tropopause is diagnosed by the abundance of an artificial tracer e90 (Prather et al., 2011; Tang et al., 2011), which has been demonstrated to match the traditional, but moreawkward-for-our-model definitions. The emissions are taken from the European Union Quantifying the Climate Impact of Global and European Transport Systems (QUANTIFY) project Year-2000 inventory (Hoor et al., 2009). Advection uses the second order moment scheme (Prather, 1986), and the convection scheme follows Tiedtke (1989).

\section{Ozone sonde data}

In this study, we use the World Ozone and Ultraviolet Radiation Data Centre (WOUDC) ozone sondes in years 20052006 from 42 stations (http://www.woudc.org, retrieved on 10 November 2010) for latitudes $65^{\circ} \mathrm{S}-65^{\circ} \mathrm{N}$, which covers most folding events found in the model. The modeled ozone profiles generally match sondes (see Tang and Prather, 2010, Fig. 1). The search criteria for identifying TFs follows the algorithm in Tang and Prather (2010): proceeding upward from the surface, we tag the first layer above $5 \mathrm{~km}$ altitude at which the $\mathrm{O}_{3}$ abundance exceeds $80 \mathrm{ppb}$ (parts per billion, nanomoles per mole of air) and continue upward recording the maximum abundance; then if it decreases by at least $20 \mathrm{ppb}$ relative to the maximum within the $3 \mathrm{~km}$ above the peak to a minimum value less than $120 \mathrm{ppb}$, it is a fold.

\section{Aura ozone data and method}

The EOS Aura satellite, launched on 15 July 2004, carries four instruments (HIRDLS, MLS, OMI, and TES) that observe ozone (Schoeberl et al., 2006). Aura flies on a sunsynchronous orbit with a $98^{\circ}$ inclination and an ascending equator-crossing time of 13:45 local time. The orbit is $705 \mathrm{~km}$ above the sea level with a 16-day repeat period. A single orbit takes $\sim 98 \mathrm{~min}$. In this study, we use the level 2 (L2) swath data from all the four instruments. Many studies of the Aura ozone data use averaged L2 data or L3 data (typically averaged over a month over large grid cells), both of which smear the true meteorological variability and the folding events. 

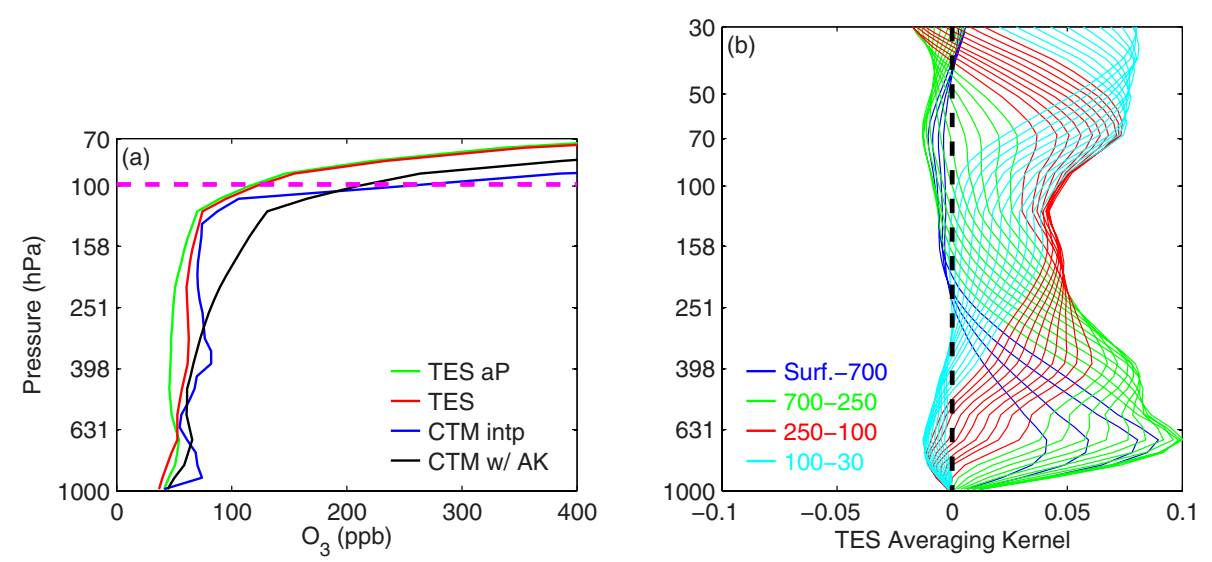

Fig. 1. Comparisons between TES a priori (green), TES (red), linearly interpolated CTM on TES levels (blue) and convolved CTM (black) ozone profiles (a, unit: ppb) and the corresponding TES averaging kernel (AK, b) as a function of pressure at $9.5^{\circ} \mathrm{S}, 295.0^{\circ} \mathrm{E}$ on 25 August 2005. In panel (a), dashed magenta line shows the e 90 tropopause of $99 \mathrm{hPa}$. The AK for different pressure ranges are represented by solid lines in (b): blue for surface-700 hPa, green for 700-250 hPa, red for 250-100 hPa, and cyan for 100-30 hPa. The dashed black line in (b) shows the zero line. The DOFS for the troposphere and the whole atmosphere are 1.5 and 4.0, respectively.
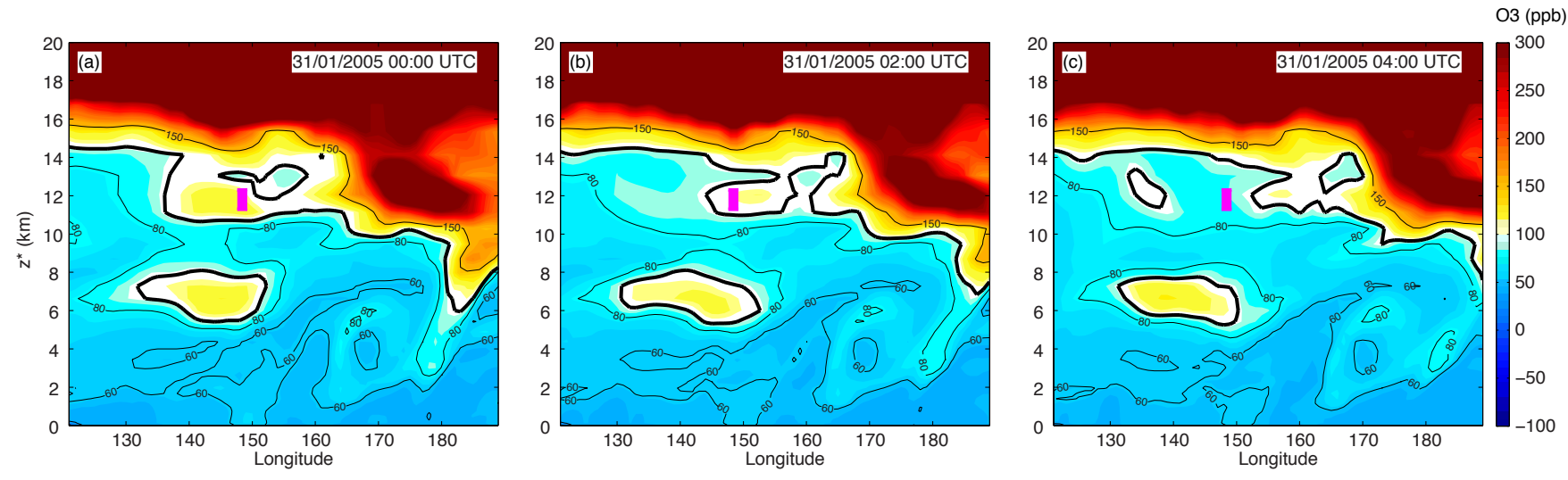

Fig. 2. Pressure altitude $\left(z^{*}\right)$ by longitude $\left(120^{\circ} \mathrm{E}-190^{\circ} \mathrm{E}\right)$ plots of simulated ozone (colors: blue shows low values, red high values, unit: ppb) at $29.5^{\circ} \mathrm{N}$ on 31 January 2005 (a) 00:00 UTC, (b) 02:00 UTC, and (c) 04:00 UTC. The thin black contour lines represent ozone of 60,80 , and $150 \mathrm{ppb}$. The thick black contour lines define the 100-ppb ozone surface (approximately the tropopause). The magenta squares correspond to the same CTM grid box.

\subsection{HIRDLS}

HIRDLS observes the atmosphere in limb direction at 21 infrared channels from 6.12 to $17.76 \mu \mathrm{m}$ (HIRDLS Team, 2010). After launch a spacecraft malfunction resulted in $\sim 80 \%$ blockage of its optical path which limited the coverage from $65^{\circ} \mathrm{S}$ to $82^{\circ} \mathrm{N}$, missing the Antarctic. With its limited field of view at one azimuth angle, however, HIRDLS can still retrieve ozone profiles $(260-0.5 \mathrm{hPa})$ with high vertical resolution $(\sim 1 \mathrm{~km})$. These continuous observations at one azimuth can facilitate studies on short-lived processes (e.g., gravity waves (Alexander et al., 2008)) and possibly TFs. Because of this failure, HIRDLS is not able to measure the same atmospheric profile as the rest Aura instruments within $15 \mathrm{~min}$, but instead views the same location $84 \mathrm{~min}$ earlier than MLS at night and $17^{\circ}$ to the east of the MLS track during the daytime.

We use version 5 (v5.00.00) HIRDLS ozone data in this study. The data with negative "O3Precision" or earthward from the nearest and above the "CloudTopPressure" are screened out. The "gradient filter" is not applied, because high vertical ozone gradient exists when tropopause folds occur. Note that without the "gradient filter" some unrealistically high ozone spikes are not excluded (see Figs. $3 g$ and $4 g$ ). 

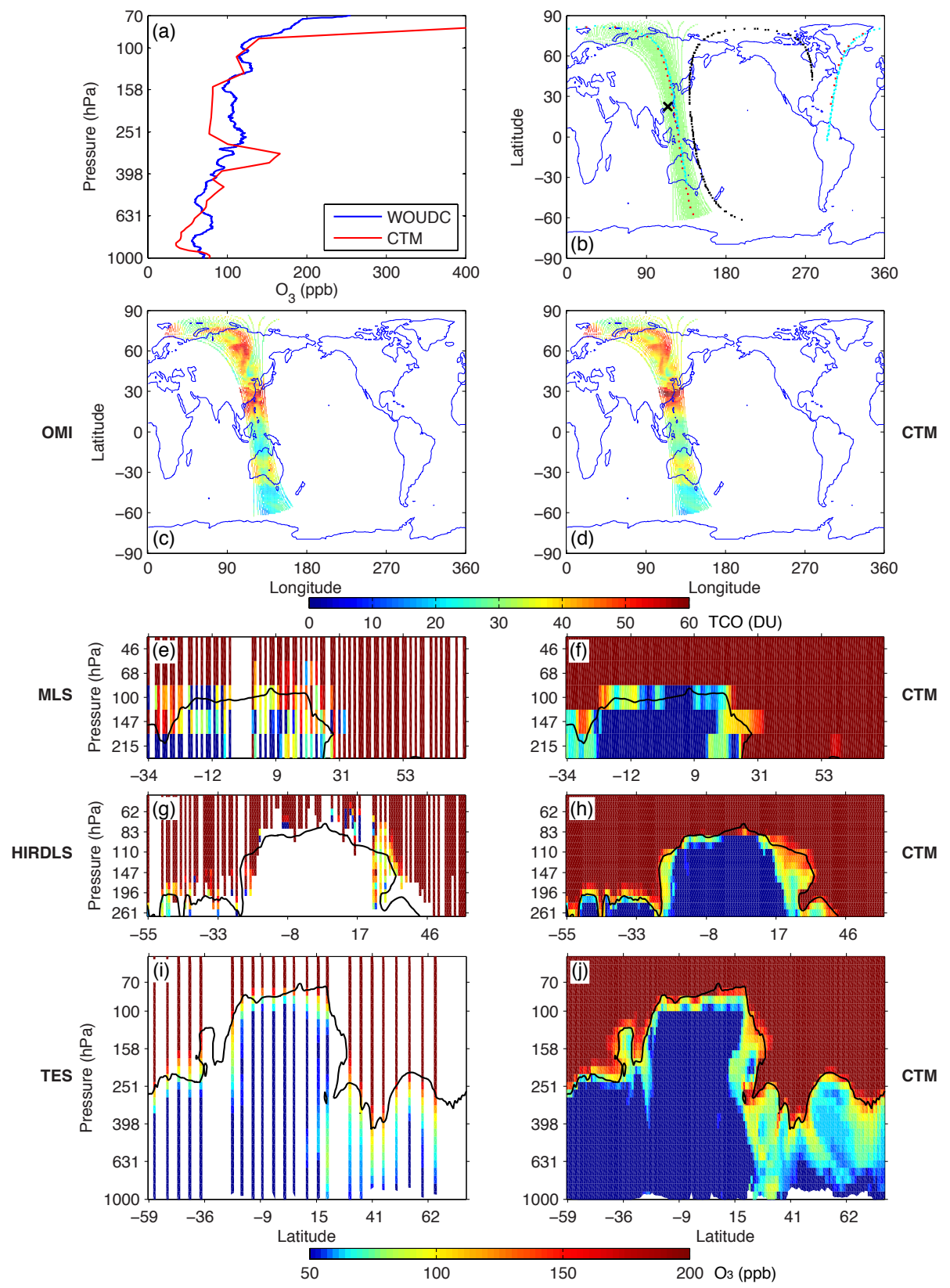

Fig. 3. Comparisons between sonde and Aura ozone swaths with CTM for 23 March 2005. (a) WOUDC sonde (blue, 05:26 UTC) vs. CTM (red, 06:00 UTC) profile (unit: ppb) at Hong Kong $\left(22.3^{\circ} \mathrm{N}, 114.2^{\circ} \mathrm{E}\right.$, station code 344$)$. (b) The locations of available Aura measurements (on the CTM grid) during 05:00-06:00 UTC. HIRDLS: black crosses, MLS: cyan crosses, TES: red crosses, OMI: green dots, sonde location in (a): the large black cross. Comparisons for Aura (left) vs. exact matching CTM results (right) swaths: (c) vs. (d) for OMI; (e) vs. (f) for MLS; (g) vs. (h) for HIRDLS; (i) vs. (j) for TES. We compare latitude-by-longitude TCO (unit: DU) for OMI swaths, pressure-by-latitude $\mathrm{O}_{3}$ molar ratios $\left(0^{\circ}-180^{\circ} \mathrm{E}\right.$, unit: ppb) for HIRDLS, MLS, and TES. The black lines in (e)-(j) represent the e90 tropopause.

\subsection{MLS}

MLS measures stratospheric and upper tropospheric ozone using microwave limb sounding technology at $240 \mathrm{GHz}$ (Schoeberl et al., 2006; Waters et al., 2006). Although the version 3.3 standard $\mathrm{O}_{3}$ product has doubled vertical resolution and an enlarged pressure range, we opt here for ver- sion 2.2 data, as oscillations appear in the tropical upper troposphere (UT) profiles of version 3.3, even for monthly mean ozone profiles (Livesey et al., 2011). The vertical resolution of MLS ozone profiles is $\sim 3 \mathrm{~km}$ in the UT and stratosphere. The horizontal resolution is $\sim 200 \mathrm{~km} \times 6 \mathrm{~km}$ (along-track $\times$ cross-track). The precision of single profile is $40 \mathrm{ppb}$ at $215-100 \mathrm{hPa}$ (Livesey et al., 2007). We extract the 
scientifically useful data from $215 \mathrm{hPa}$ to $0.02 \mathrm{hPa}$. Only data with (1) positive precision, (2) even-numbered "Status", (3) "Quality" greater than 1.2, and (4) "Convergence" less than 1.8 are used in this study.

\subsection{OMI}

OMI uses a 2-D Charge-Coupled Device to measure the backscattered solar irradiance from nadir direction at ultraviolet and visible wavelengths (UV-1: $264-311 \mathrm{~nm}, \mathrm{UV}-2$ : 307-383 nm, VIS: 349-504 nm). The wide cross-orbit swath $(2600 \mathrm{~km})$ allows OMI to provide global daily coverage (OMI Team, 2009). In this study, we use the OMO3PR V003 ozone profiles with a horizontal resolution of $13 \mathrm{~km} \times 48 \mathrm{~km}$ (along-track $\times$ cross-track) and 18 vertical layers from the surface to $0.3 \mathrm{hPa}$ (de Haan and Veefkind, 2009). In the troposphere, the vertical resolution is very coarse (3-6 layers) and thus OMI cannot resolve vertical structures such as TFs. OMI does provide useful information about the tropospheric column, including its enhancements in regions with TFs (Tang and Prather, 2010). The OMI tropospheric column ozone (TCO) is derived by applying the tropopause height output from the UCI CTM to the OMI ozone profiles.

\subsection{TES}

TES is a high resolution infrared Fourier transform spectrometer with spectral coverage from 650 to $3250 \mathrm{~cm}^{-1}$ at a spectral resolution of $0.025 \mathrm{~cm}^{-1}$. It is designed to view the atmosphere in both nadir and limb directions with a $5 \mathrm{~km} \times 8 \mathrm{~km}$ nadir footprint. The limb scan mode, however, was eliminated in 2005 to conserve instrument life. The version 4 (V004, F05_07) nadir global survey standard ozone product is used in this paper. The profiles are reported at 67 pressure levels from the surface to $0.1 \mathrm{hPa}$, but in the troposphere there are only 1-2 degrees of freedom for the signal (DOFS) (Nassar et al., 2008; Zhang et al., 2010). Ozone profiles whose "SpeciesRetrievalQuality" or "O3_Ccurve_QA" does not equal 1 are excluded (Osterman et al., 2009). Some of the TES profiles $(0.5 \%)$ contain fill values for the averaging kernel (AK), and these are also excluded.

\subsection{Methods of mapping modeled ozone profiles onto reported Aura measurements}

The CTM and Aura ozone profiles all have different locations and pressure coordinates. For geographic collocation, we choose without interpolation the $1^{\circ} \times 1^{\circ}$ model grid containing the centre (for OMI and TES) or the location of the tangent height (for HIRDLS and MLS) of the observation. Temporal differences are accounted for by interpolation between the two half-hour model simulations bounding the observation as described above. The vertical remapping is more complex and specific to each instrument. Before comparing them, we first map CTM profiles onto the Aura levels either by linear interpolation in pressure for HIRDLS and
MLS or by convolution with the a priori and averaging kernel (AK) (together referred as the satellite operator) for OMI and TES. The "least squares fit" method recommended by Livesey et al. (2007) is unstable for the lowermost MLS layers, which are particularly important for this paper. Also considering that HIRDLS and MLS have vertical resolutions comparable to that of the CTM, we decided to simply interpolate the CTM profiles onto HIRDLS and MLS levels. For OMI and TES the satellite operators are applied to the CTM profiles to account for limited vertical resolution and sensitivity of nadir viewing measurements based upon the following equation (Luo et al., 2007; Worden et al., 2007):

$\hat{\boldsymbol{x}}_{\mathrm{m}}=\boldsymbol{x}_{\mathrm{a}}+\mathbf{A}\left(\boldsymbol{x}_{\mathrm{m}}-\boldsymbol{x}_{\mathrm{a}}\right)$

where $\boldsymbol{x}_{\mathrm{a}}$ and $\mathbf{A}$ are the a priori and averaging kernel as reported in OMI and TES HDF-EOS5 metadata. The modeled ozone profiles are first interpolated onto the satellite levels. The above equation then transforms the interpolated profiles $\boldsymbol{x}_{\mathrm{m}}$ to the "retrieved" profiles $\hat{\boldsymbol{x}}_{\mathrm{m}}$, mimicking the vertical smoothing of the retrieval process of OMI and TES data. Note that $\boldsymbol{x}_{\mathrm{m}}$ is in Dobson Unit (DU) for OMI and the natural logarithm of ozone molar ratio for TES.

\subsection{Problems with applying satellite operators for nadir-view instruments}

TES contains 1-2 DOFS in the troposphere and thus provides some tropospheric profile data but less information than is apparent in the 25 tropospheric pressure levels of their retrievals (see Fig. 1). Given the sparse spatial coverage of TES in contrast with OMI, we can only infer STE processes from the changes in upper tropospheric values. Therefore, in this study we compare the CTM with TES profiles.

Convolving modeled or sonde profiles with Eq. (1) essentially smoothes those profiles vertically and relaxes them towards the retrieval a priori. For most regions, this method works adequately and smoothes the profiles as expected. In the UT, however, applying the satellite operator can cause unphysically high biases (see Fig. 1a and Table 1).

Figure 1a shows the comparison for one of the TES profiles in Fig. $4 \mathrm{i}$ at $9.5^{\circ} \mathrm{S}, 295.0^{\circ} \mathrm{E}$. The TES profile (red line) contains a slight inversion at $630 \mathrm{hPa}$, determined mainly by its a priori (green line), and a dispersed fold at $600-$ $200 \mathrm{hPa}$ that is primarily contributed by the TES signal. From $120 \mathrm{hPa}$ to $70 \mathrm{hPa}$, TES values are almost identical to a priori values. The linearly interpolated CTM profile (blue line) also resolves the two folds, but with larger magnitudes. The modeled profile matches the shape as well as the magnitude retrieved by TES in the UT. Applying the TES operator, the CTM profile (black line) still has the fold at $630 \mathrm{hPa}$, but the vertical gradient becomes smoother and the shape is quite similar to the a priori estimate. However, the fold at $400 \mathrm{hPa}$ is totally smoothed out and the ozone abundance increases monotonically above $400 \mathrm{hPa}$ with a much larger slope than that of TES, the TES a priori, or the raw CTM profile in the 
Table 1. Means and root mean squares (RMS) of the exact matching TES and CTM partial ozone columns (unit: DU) of the TES swath shown in Fig. $4 \mathrm{i}$ covering $31.5^{\circ} \mathrm{S}-71.4^{\circ} \mathrm{N}$ with 54 individual profiles ${ }^{\mathrm{a}}$.

\begin{tabular}{lrrrrr}
\hline Regions & CTM $( \pm \sigma)$ & CTM $^{*}$ & TES & CTM $^{\prime}-$ TES $^{\prime}$ & CTM $^{* \prime}-$ TES $^{\prime}$ \\
\hline Upper Trop. (400 hPa-TPP) & $13.1( \pm 3.1)$ & 16.1 & 14.1 & 3.3 & 3.4 \\
Mid Trop. (700-400 hPa) & $12.8( \pm 2.0)$ & 12.1 & 11.1 & 1.9 & 1.7 \\
Lower Trop. (surf.-700 hPa) & $12.1( \pm 3.1)$ & 9.9 & 9.3 & 2.0 & 1.6 \\
\hline
\end{tabular}

a Single values are the means, while the differences are the RMS of anomalies (e.g., $\mathrm{CTM}^{\prime}=\mathrm{CTM}-\overline{\mathrm{CTM}}$ ). CTM* represents the CTM values processed with the TES operator.

UT, resulting in unrealistically large $\mathrm{O}_{3}$ abundances in the UT. Smearing stratospheric information into the troposphere by the TES retrieval process is also noted in other studies (Osterman et al., 2008).

The artificially high bias in the UT introduced by applying the TES operator reflects: (i) the model's high bias relative to TES in the lower stratosphere, (ii) TES's coarse vertical resolution around the tropopause, and (iii) the large crosstropopause ozone gradient. The AK for this particular measurement is shown in Fig. 1b. It is generally thick, indicating coarse vertical resolution. Although data is reported at 67 levels, the DOFS of this measurement (i.e., the trace of the $\mathrm{AK})$ are 4.0 for all levels, 1.5 for the troposphere, and 0.5 for the UT (250-100 hPa). The UT retrievals are strongly influenced by the layers at $100-50 \mathrm{hPa}$ and $400-250 \mathrm{hPa}$, which have contributions as large as those of the UT region itself (red lines in Fig. 1b). Therefore, the large stratospheric differences between the TES a priori (green line in Fig. 1a) and the raw CTM profile (blue line in Fig. 1a) are smoothed and aliased into the UT, swamping the clear UT signal in the model, and leading to the high model biases in this region.

Table 1 shows the means, standard deviations $(\sigma)$, and the root mean squares (RMS) of the partial columns for TES and matching CTM profiles for the swath shown in Fig. 4i. This swath consists of 54 individual profiles, covering $31.5^{\circ} \mathrm{S}-$ $71.4^{\circ} \mathrm{N}$. In the upper troposphere ( $400 \mathrm{hPa}$-tropopause), the raw CTM mean (second column) is $7 \%$ smaller than TES (fourth column). After processing with the TES operator, the CTM mean (third column) is enhanced by 3.0 DU (almost $1 \sigma)$ and becomes $14 \%$ larger than TES. In the middle (700$400 \mathrm{hPa}$ ) and lower (surface-700 hPa) troposphere, the CTM means using the TES operator become smaller and closer to the TES means. The RMS of anomalies (column 5 and 6) is increased by the operator in the UT, but reduced in the middle and lower troposphere.

The results in Table 1 are typical and suggest that applying the TES operator causes artificially high biases in the UT over most latitudes. This is also true for OMI, whose vertical resolution is even coarser than TES. One possible solution for this problem is to redo the TES retrieval process using our modeled profiles as the a priori, but this would be an extensive effort beyond the scope of this paper. Because the UT region is greatly affected by the STE processes (Terao et al., 2008), on which this paper focuses, we decided to compare the interpolated CTM profiles directly with TES on TES pressure levels in the following case studies (Sect. 6.1), and we show results both with and without the TES operator for the rest of the analysis. Our problems when using satellite operators highlight the fact that to avoid misusing and/or misinterpreting satellite data, it is important to know the sensitivities and resolutions of satellite measurements, especially in regions with large gradients like the tropopause. If the real ozone in the lower stratosphere was actually much higher than the retrieval a priori, TES would put too much ozone in the UT similar to the convolved model results.

The artificially high bias of local $\mathrm{O}_{3}$ abundances caused by applying nadir satellite operators in the UT, however, appears to have only a small effect on the tropospheric column ozone (TCO) as shown by the sums of the second and third columns (38.0 DU vs. 38.1 DU) of Table 1. As mentioned above the TES DOFS in the troposphere are generally greater than one (Zhang et al., 2010) and thus give reasonable TCO values. Likewise, OMI has typically DOFS of 1 for the troposphere (de Haan and Veefkind, 2009), and its TCO matches the simulation in terms of geographical patterns and magnitudes (Tang and Prather, 2010). Therefore, when comparing the TCO of TES or OMI with the model results, we process CTM profiles with the satellite operators.

\section{Temporal and spatial scales of STE}

Knowledge of the temporal and spatial scales of STE-related processes is important for investigating stratospheric ozone influx. Figure 2 illustrates the high variability of STE with three snapshots at 2-h intervals of the simulated ozone cross sections as a function of pressure altitude $\left(\mathrm{z}^{*} \mathrm{~km}=16 \times\right.$ $\log _{10}(1000 / p \mathrm{hPa})$ ) and longitude at $29.4^{\circ} \mathrm{N}$ starting on 31 January 2005 at 00:00 UTC. The tropopause folding structures, outlined by the thick black lines designating $\mathrm{O}_{3}$ abundance of 100-ppb suggest cross-tropopause mixing. The magenta squares mark the same CTM grid box and highlight the short-lived feature of tropopause folds. In Fig. 2a, the magenta box is located in the stratospheric part of a TF beneath an apparently isolated tropospheric air mass, which is actually connected with the troposphere at another latitude. Two hours later, another TF develops and its tropospheric branch 

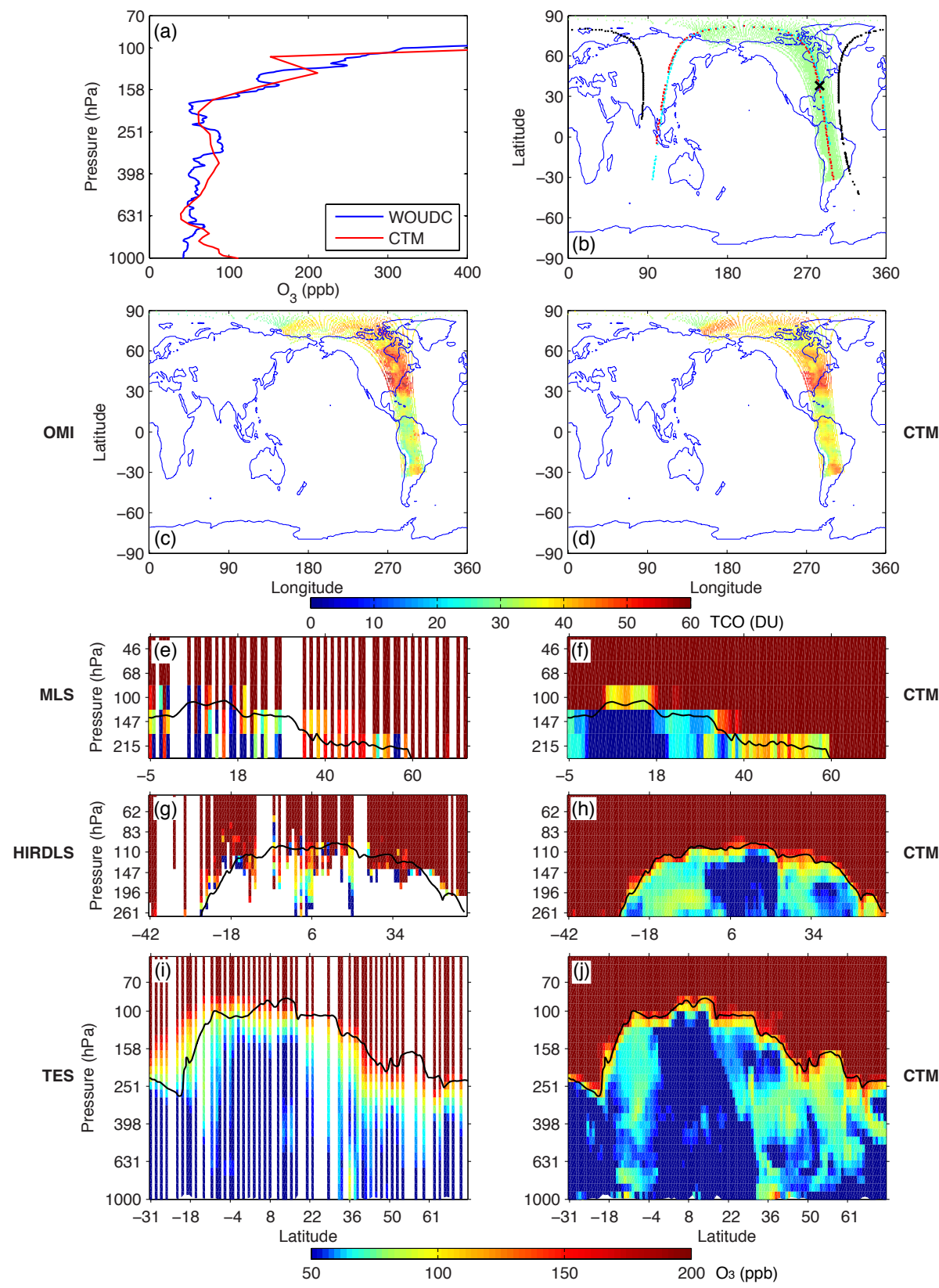

Fig. 4. Same as Fig. 3 for 25 August 2005. The sonde is from Wallops Island ( $37.9^{\circ}$ N, $75.5^{\circ}$ W, station code 107) at 17:39 UTC, compared with model simulation at 18:00 UTC in (a). The Aura and CTM swaths are for 18:00-19:00 UTC. (c)-(j) show the swaths in $180^{\circ}$ E-360 ${ }^{\circ}$.

extends over the box (Fig. 2b). The isolated tropospheric air mass in Fig. 2a reconnects with the troposphere at $\sim 10^{\circ}$ east in Fig. 2b. The folds continue moving to the east and the box is in the troposphere two hours later (Fig. 2c). An isolated stratospheric air mass $\left(140^{\circ} \mathrm{E}\right)$ and tropospheric air mass $\left(170^{\circ} \mathrm{E}\right)$ also emerge at $12-14 \mathrm{~km}$ in Fig. $2 \mathrm{c}$. The stratospheric air stays deep in the troposphere $\left(130^{\circ} \mathrm{E}-150^{\circ} \mathrm{E}\right.$, 6-8 km) with little change over 6-h, indicating a significant stratospheric intrusion and showing that the STE process can be relatively long-lived. Given the objective of identifying
TFs, we must compare with the Aura level 2 (L2) swath data instead of the L2 averaged data or the L3 gridded data that are averaged over two weeks or more. Figure 2 also indicates that the STE processes occur on the scale of a few hundred kilometers and require model resolutions of about $1^{\circ}$ to match the observations. 


\section{Results}

\subsection{Case studies}

We select our case studies of tropopause folds to ensure that the most precise measurement of tropopause folds (i.e., the ozone sonde) observes a folding event, that the OMI swath overlaps the sonde measurement within one hour, and that all four Aura measurements are available. Out of the 1907 WOUDC ozone sondes and the $\sim 10000$ Aura swaths, there are eight such cases in year 2005 . Two of these cases are shown in Figs. 3 and 4 here, while the remaining six are in the appendix (Figs. A1-A6). In Fig. 3, the sonde profile is measured at Hong Kong $\left(22.3^{\circ} \mathrm{N}, 114.2^{\circ} \mathrm{E}\right.$, station code 344) on 23 March 05:26 UTC and the Aura and CTM swaths are for 05:00-06:00 UTC. The case in Fig. 4 shows the sonde at Wallops Island $\left(37.9^{\circ} \mathrm{N}, 75.5^{\circ} \mathrm{W}\right.$, station code 107$)$ for 25 August 17:39 UTC and Aura and CTM swaths for 18:0019:00 UTC.

The modeled ozone profiles (red line) are compared with the sondes (blue line) in Figs. 3a and 4a. The CTM profiles are from the $1^{\circ} \times 1^{\circ}$ grid boxes containing the sonde stations and temporally closest in the 2-h output field (06:00 UTC for Fig. 3a and 18:00 UTC for Fig. 4a). In the first case, the model and sonde have the same main shape (Fig. 3a): ozone decreases with height in the boundary layer (1000-800 hPa) and increases in the free troposphere with a clear inversion in the upper troposphere and another one of smaller magnitude at $125 \mathrm{hPa}$. The CTM misses the high values around $700 \mathrm{hPa}$. The CTM profile has larger variance in the free troposphere. The middle troposphere maximum seen in the sonde (300$200 \mathrm{hPa})$ occurs lower in the CTM $(400-300 \mathrm{hPa})$ and is attributable to a TF. The model slightly underestimates the magnitude of the folding at $125 \mathrm{hPa}$. In the second case, the model reproduces the magnitude of the folding structure at $300 \mathrm{hPa}$ with the peak point about $30 \mathrm{hPa}$ lower in altitude, but overestimates the variance at the tropopause $(120 \mathrm{hPa}$, Fig. $4 \mathrm{a})$. These two comparisons reveal that the model matches the sonde in the shape and magnitude, in particular resolving the folds, and give us some confidence that the model should be capable of reproducing the folding structures and patterns in the nearly concurrent Aura swaths.

The locations of each available Aura measurement (HIRDLS: black crosses, MLS: cyan crosses, OMI: green dots, TES: red crosses) in the one hour period close to the sonde measurement are shown on the CTM grids in Figs. 3b and $4 \mathrm{~b}$. Note that although the swaths of MLS and TES nearly overlap, MLS measurements are a few minutes ahead of TES as MLS performs forward limb scan, whereas TES views in nadir direction. Only OMI and TES can have exactly matching measurements in both time and location. The large black crosses represent the sonde locations. Comparisons between Aura and CTM matched swaths are represented in Fig. 3c-d for OMI, Fig. 3e-f for MLS, Fig. 3g-h for HIRDLS, and Fig. 3i-j for TES. Parallel structure and notation are used in plots of the other case studies (Figs. 4 and A1-A6). Each Aura measurement is compared with the coincident model result for the grid box containing the centre of the Aura observation. The modeled profiles are interpolated onto the corresponding Aura levels for the comparisons. The white spaces in the Aura swaths (panels c, e, g, i of Figs. 3 and 4) indicate either no measurements or bad values. The CTM swaths, by contrast, show all profiles along the orbit to present a continuous picture. White areas in Figs. $3 \mathrm{j}$ and $4 \mathrm{j}$ reflect topography. The black lines imposed on the vertical swaths represent the tropopause at each measurement location as determined by the artificial tracer e90 in the CTM (Prather et al., 2011). For OMI, we compare the CTM with only the TCO as a function of latitude and longitude, since OMI has a DOFS of 1 in the troposphere (de Haan and Veefkind, 2009). For the remaining three Aura instruments, the comparisons are performed for the pressure-bylatitude cross-sections of each swath for $0^{\circ}-180^{\circ} \mathrm{E}$ in Fig. 3 and $180^{\circ} \mathrm{E}-360^{\circ} \mathrm{E}$ in Fig. 4. Note that TES also contains 1-2 tropospheric DOFS, but its footprints are too sparse to allow it infer STE from TCO anomalies alone (as for OMI) and thus the combination of upper troposphere changes in TES profiles and simulated geographical pattern of the fold is used here to validate the modeled folds.

The model simulates the OMI TCO swath quite well (see Figs. $3 \mathrm{c}-\mathrm{d}$ and $4 \mathrm{c}-\mathrm{d})$ as previously shown by Tang and Prather (2010). Here, the CTM profiles are convolved with the OMI operator to account for the limited vertical resolution and sensitivity of OMI, whereas Tang and Prather (2010) use the raw CTM profiles. The convolution does not have great impact on the CTM TCO. The OMI TCO uses the tropopause height calculated by the CTM to make consistent comparisons. In Fig. 3c-d, high TCO appears over Northern and Eastern Asia as well as Australia in both OMI and CTM. The geographic patterns match in details, such as the curvature in Northern Asia. The OMI TCO swath contains more high-frequency variability, likely to be noise, than does the CTM. Figure $4 c-d$ show similar results. Both CTM and OMI have high TCO over North and South America. The CTM, however, underestimates TCO over North America and overestimates it over South America. The biases are within \pm 5 DU. The high anomalies in TCO are correlated with TF events, particularly near the subtropical jet streams (Tang and Prather, 2010) and hence can provide clues about whether the folding structures in MLS and TES swaths are realistic.

MLS and CTM have similar $\mathrm{O}_{3}$ patterns just above the tropopause with the typical lower stratospheric values $(>200 \mathrm{ppb})$ at $68 \mathrm{hPa}$ in the tropics and at $215 \mathrm{hPa}$ in the extra-tropics. The tropics-to-midlatitude transition from troposphere to stratosphere is the same in both: $23^{\circ} \mathrm{S}$ at $100 \mathrm{hPa}$ and $30^{\circ} \mathrm{N}$ at $215 \mathrm{hPa}$ in Fig. $3 \mathrm{e}-\mathrm{f}$; and $18^{\circ} \mathrm{N}$ at $100 \mathrm{hPa}$ and $60^{\circ} \mathrm{N}$ at $215 \mathrm{hPa}$ in Fig. 4e-f. MLS reports inversion structures near $13^{\circ} \mathrm{S}$ at $147-100 \mathrm{hPa}$ (Fig. 3e), which are not found in the CTM swath (Fig. 3f). The corresponding OMI 
and CTM TCO do not show high anomalies around $13^{\circ} \mathrm{S}$, and thus these inversions in the MLS data are probably noise in the MLS retrieval procedure. The folding structures at $15^{\circ} \mathrm{N}-30^{\circ} \mathrm{N}$ are consistent in MLS and CTM swaths and confirmed by the TCO high anomalies. As expected from the single-profile precision of MLS in this region, some unphysical values emerge in the MLS data with no analogues in the model, such as $>200 \mathrm{ppb} \mathrm{O}_{3}$ at $215 \mathrm{hPa}$ near the equator, $70 \mathrm{ppb}$ at $68 \mathrm{hPa}$ at $20^{\circ} \mathrm{N}$ (Fig. 3e), and $>200 \mathrm{ppb}$ at $147 \mathrm{hPa}$ at $12^{\circ} \mathrm{N}$ (Fig. 4e). These are likely due to contamination from thick clouds.

For HIRDLS, most of the tropospheric values are missing for the tropics below the tropopause as they are obscured by the presence of high clouds in the troposphere (Figs. $3 \mathrm{~g}$ and $4 \mathrm{~g}$ ). The tropopause region in HIRDLS swaths appears more fuzzy and diffused with some non-physically low values $(<50 \mathrm{ppb})$ in the stratosphere (e.g., $17^{\circ} \mathrm{N}$ at $70 \mathrm{hPa}$ in Fig. $3 \mathrm{~g})$ and unrealistically high values $(>200 \mathrm{hPa})$ in the troposphere (e.g., $7^{\circ} \mathrm{N}$ at $130 \mathrm{hPa}$ and $10^{\circ} \mathrm{S}$ at $196 \mathrm{hPa}$ in Fig. 4g). These unrealistic values reflect the fundamental difficulty with HIRDLS or any limb scanning instrument of quantifying ozone abundances as they decline rapidly below the tropopause. Some of the non-physical, high abundances may be screened out as "high spikes" (HIRDLS Team, 2010). On the other hand, HIRDLS does observe some tropospheric patterns that match the CTM, such as the high- $\mathrm{O}_{3}$ spot at $150 \mathrm{hPa}$ near $30^{\circ} \mathrm{N}$ in Fig. $3 \mathrm{~g}$ and the low values at $230 \mathrm{hPa}$ near $21^{\circ} \mathrm{N}$ in Fig. 4g. Given the fine vertical resolution $(\sim 1 \mathrm{~km})$, HIRDLS can resolve major STE events, following stratospheric air well into the troposphere (see Pan et al., 2009, for a case on 11 May 2007), but we did not find these in our test cases for 2005-2006.

Observing at nadir angles, TES is able to retrieve the ozone profile down to the ground, but the vertical resolution is much coarser than MLS, HIRDLS, and the CTM in the UT/LS region. The profiles in the TES swaths (Figs. 3i and $4 \mathrm{i}$ ) are much smoother compared to the CTM simulation, catching the main components and patterns but missing much of the details. In Fig. 3i-j, both TES and the CTM display high ozone abundances about $20^{\circ} \mathrm{N}$ at $631 \mathrm{hPa}$ and $42^{\circ} \mathrm{N}$ at $400 \mathrm{hPa}$ plus the displacement of stratospheric air (with $\mathrm{O}_{3}>200 \mathrm{ppb}$ ) down to a typical troposphere regime $\left(38^{\circ} \mathrm{N}-50^{\circ} \mathrm{N}, 400-250 \mathrm{hPa}\right)$, indicating stratospheric intrusions. The locations of these intrusions match the cyclonic pattern in observed and simulated OMI swaths (Fig. 3cd). TES, however, does not show the intrusion structures at $20^{\circ} \mathrm{N}$ at 280 and $158 \mathrm{hPa}$. In Fig. $4 \mathrm{i}-\mathrm{j}$, high $\mathrm{O}_{3}(\sim 80 \mathrm{ppb})$ values are found near $10^{\circ} \mathrm{S}$ at $350 \mathrm{hPa}$ in both TES and the CTM, but the hot spot at $700 \mathrm{hPa}$ at that latitude, probably due to biomass burning, is seen only in the CTM. TES shows the high- $\mathrm{O}_{3}$ anomaly at $37^{\circ} \mathrm{N}$ in the lowermost troposphere, which may possibly be understood as the folding structure aloft (predicted by the CTM) being redistributed by the TES AK (Fig. 1b) into the lowermost troposphere to give reasonable TCO. The enhanced ozone at $15^{\circ} \mathrm{N}, 400 \mathrm{hPa}$ is similar in both. The tropospheric inversion patterns simulated by the $\mathrm{CTM}$ at $30^{\circ} \mathrm{N}-60^{\circ} \mathrm{N}$ are seen as a broad area of enhanced $\mathrm{O}_{3}$ by TES.

The other six cases (Figs. A1-A6) show very similar results as the above two cases for different locations and time. In one case (Fig. A2, 6 July 2005) the CTM reproduces the large stratospheric fold at $200 \mathrm{hPa}$ as seen by the sonde, and the MLS and CTM patterns match quite well in Fig. A2e$\mathrm{f}$, except for the magnitudes of a few points. HIRDLS observes a stratospheric intrusion at $45^{\circ} \mathrm{N}, 260-200 \mathrm{hPa}$, also in agreement with the model. In Fig. A4 (3 August 2005) TES matches the CTM intrusion patterns at $25^{\circ} \mathrm{S}-10^{\circ} \mathrm{S}$, $630-160 \mathrm{hPa}$ and at $40^{\circ} \mathrm{N}-50^{\circ} \mathrm{N}, 450-250 \mathrm{hPa}$. In Fig. A6 (19 December 2005) TES and CTM agree on the intrusion patterns at $20^{\circ} \mathrm{N}, 400-150 \mathrm{hPa}$ as well as the high- $\mathrm{O}_{3}$ region at $19^{\circ} \mathrm{S}-5^{\circ} \mathrm{S}, 630-400 \mathrm{hPa}$, although the TES pattern is more spread out and lower in altitude.

Olsen et al. (2008) found a tropospheric intrusion within the stratosphere extending from the tropics to high latitudes in the HIRDLS data (v004) on 26 January 2006. Figure A7 presents this case in the same way as the above eight cases except that there is no sonde available and the color scale is adjusted to emphasize the stratospheric $\mathrm{O}_{3}$. In the new HIRDLS version (v5.00.00), the 2-km thick intrusion is also found near $110 \mathrm{hPa}$ at $30^{\circ} \mathrm{N}-55^{\circ} \mathrm{N}$ (see Fig. A7g). Figure $\mathrm{A} 7 \mathrm{~h}$ simulates this low $\mathrm{O}_{3}$ layer at the same location, but the $\mathrm{O}_{3}$ abundance in the surrounding air biases high relative to the HIRDLS measurements due to known problems with the stratospheric meteorology (Hsu and Prather, 2009). The MLS swath (Fig. A7e) indicates an inversion structure at $52^{\circ} \mathrm{N}, 100 \mathrm{hPa}$, which does not appear in the simulation (Fig. A7f).

These cases studies of the five Aura ozone measurements and the CTM simulations, made on an instantaneous basis, confirm the model's ability of reproducing the STE processes and show that the Aura measurements can detect some of the fine structures in $\mathrm{O}_{3}$, such as TFs and stratospheric intrusions deep into the troposphere, while they miss a large number of such cases, presumably due to instrumental noise, lack of sensitivity, and vertical resolution in individual measurements. Like others, we find that the Aura measurements can resolve stratosphere-troposphere folds for specific cases (Olsen et al., 2008; Manney et al., 2009; Pan et al., 2009; Manney et al., 2011). Combined with the 4-D hindcasts using the CTM or with a data assimilation system, they may lead to a general, comprehensive integration of the global STE flux, but more work is needed.

\subsection{CTM vs. Aura instantaneous comparisons}

The observations of the three Aura ozone profilers HIRDLS, MLS, and TES - do not coincide each other. They do not look at the same air mass at the same time and have dramatically different profiling techniques. From the point of view of using the Aura observations to map out rapidly 

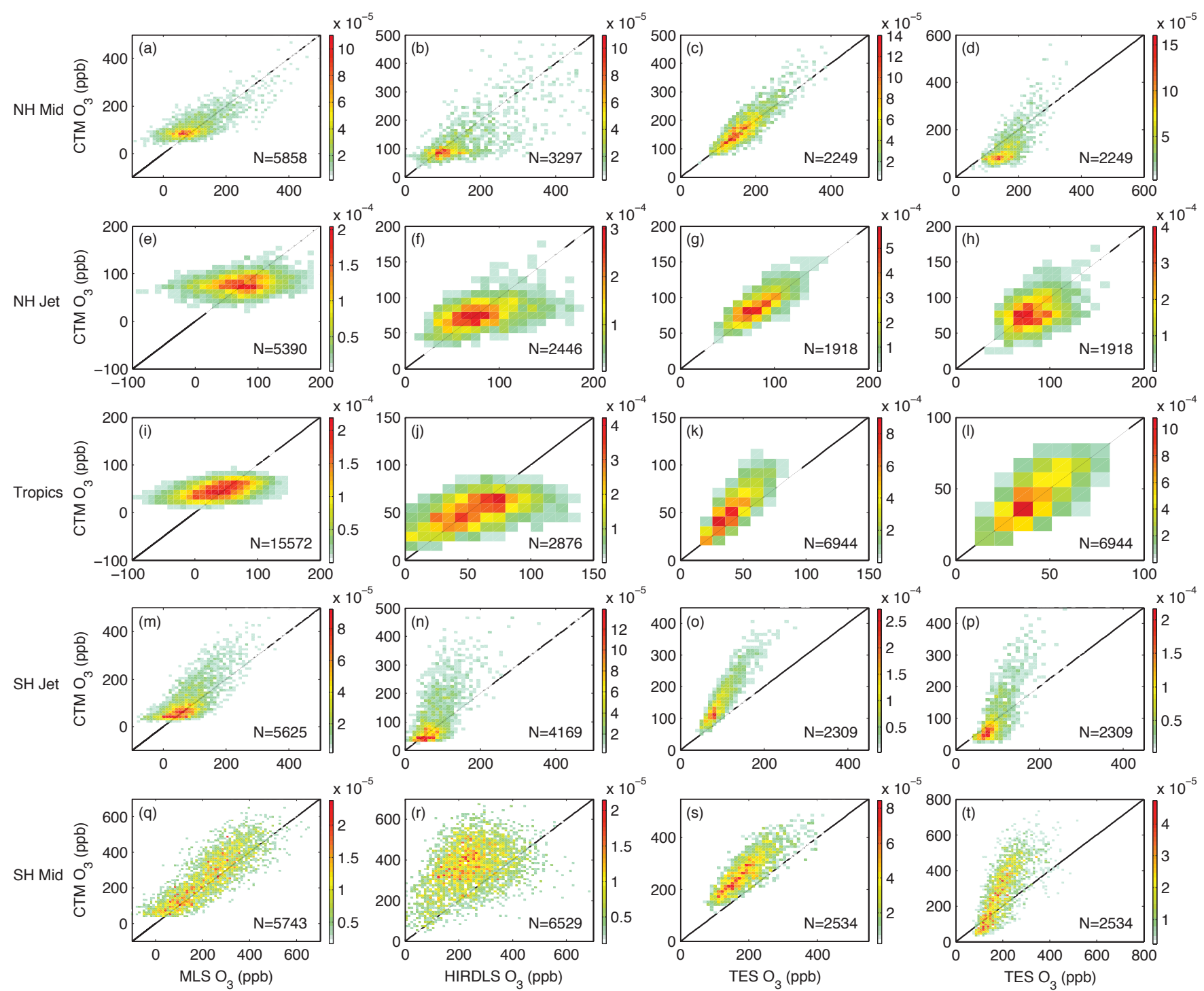

Fig. 5. 2-D probability density functions (PDFs, unit: $\mathrm{ppb}^{-2}$ ) of CTM vs. Aura $\mathrm{O}_{3}$ for July 2005 at $215 \mathrm{hPa}$. Rows from top to bottom are for $\mathrm{NH}$ middle latitudes $\left(40^{\circ} \mathrm{N}-50^{\circ} \mathrm{N}\right)$, $\mathrm{NH}$ jet $\left(25^{\circ} \mathrm{N}-35^{\circ} \mathrm{N}\right)$, tropics $\left(15^{\circ} \mathrm{S}-15^{\circ} \mathrm{N}\right)$, SH jet $\left(35^{\circ} \mathrm{S}-25^{\circ} \mathrm{S}\right)$, and $\mathrm{SH}$ middle latitudes $\left(50^{\circ} \mathrm{S}-40^{\circ} \mathrm{S}\right)$. Comparisons for different Aura ozone datasets are presented in columns from left to right: MLS, HIRDLS, and TES. The CTM results processed with the TES operator are shown in the third column, and the raw model results in the fourth column. The 2-D PDF includes all the good CTM-Aura pairs in the month and is weighted by the inverse of observation times for each latitude. It is normalized to give a 2-D integral of $1 . N$ is the number of comparisons and the solid black line shows the 1:1 line. The mean biases and RMS are given in Table 2 .

changing tropopause folds and stratospheric intrusions, we need a 4-D description of atmospheric $\mathrm{O}_{3}$ to determine if these instruments are measuring the same ozone. In this section, we use the UCI CTM as an intercomparison platform to study the consistency amongst the Aura ozone datasets focusing on the UT/LS regions.

The 2-D probability density functions (PDFs) of the CTM vs. MLS, HIRDLS, and TES are shown for July 2005 and January 2006 at $215 \mathrm{hPa}$ and $147 \mathrm{hPa}$ in Figs. 5-8. These PDFs include every exact-match, CTM-Aura pair for five latitude zones: $\mathrm{NH}$ middle latitude $\left(40^{\circ} \mathrm{N}-50^{\circ} \mathrm{N}\right), \mathrm{NH}$ jet $\left(25^{\circ} \mathrm{N}-35^{\circ} \mathrm{N}\right)$, tropics $\left(15^{\circ} \mathrm{S}-15^{\circ} \mathrm{N}\right)$, SH jet $\left(35^{\circ} \mathrm{S}-25^{\circ} \mathrm{S}\right)$, and SH middle latitude $\left(50^{\circ} \mathrm{S}-40^{\circ} \mathrm{S}\right)$. For TES, we present the comparisons for both the raw CTM simulation (fourth column) and that convolved with the TES operator (third column). The PDF (unit of frequency per $\mathrm{ppb}^{2}$ ) is weighted inversely by the sampling times for each latitude to account for unequal observations from different latitudes, and it is normalized to give an integral of 1 . The number of CTM-Aura exact matches for the month are shown on each panel. 
Table 2. Mean biases and RMS errors (unit: ppb) of CTM versus MLS, HIRDLS, and TES for five regions at $215 \mathrm{hPa}$ and $147 \mathrm{hPa}$ for July $2005^{\mathrm{a}}$.

\begin{tabular}{|c|c|c|c|c|c|c|c|c|}
\hline \multirow[b]{2}{*}{ Regions } & \multicolumn{2}{|c|}{ MLS } & \multicolumn{2}{|c|}{ HIRDLS } & \multicolumn{2}{|c|}{ TES } & \multicolumn{2}{|c|}{ TES* } \\
\hline & $215 \mathrm{hPa}$ & $147 \mathrm{hPa}$ & $215 \mathrm{hPa}$ & $147 \mathrm{hPa}$ & $215 \mathrm{hPa}$ & $147 \mathrm{hPa}$ & $215 \mathrm{hPa}$ & $147 \mathrm{hPa}$ \\
\hline NH Mid-L & $10.0 \pm 79.2$ & $51.6 \pm 125.6$ & $-48.1 \pm 186.7$ & $34.8 \pm 144.1$ & $7.9 \pm 42.1$ & $23.7 \pm 75.8$ & $-22.2 \pm 79.8$ & $-5.1 \pm 154.0$ \\
\hline NH Jet & $7.0 \pm 57.0$ & $11.7 \pm 135.6$ & $-15.1 \pm 60.9$ & $-32.6 \pm 157.5$ & $5.1 \pm 25.0$ & $11.1 \pm 53.8$ & $-2.8 \pm 34.1$ & $-5.3 \pm 105.9$ \\
\hline Tropics & $8.6 \pm 45.3$ & $-12.2 \pm 151.8$ & $-6.6 \pm 34.5$ & $-63.3 \pm 183.2$ & $11.7 \pm 17.7$ & $21.0 \pm 41.3$ & $2.5 \pm 17.8$ & $-5.3 \pm 85.6$ \\
\hline SH Jet & $42.3 \pm 80.0$ & $150.7 \pm 162.1$ & $58.4 \pm 109.6$ & $136.0 \pm 174.9$ & $72.6 \pm 69.7$ & $129.6 \pm 113.7$ & $34.8 \pm 84.1$ & $133.6 \pm 159.3$ \\
\hline SH Mid-L & $43.7 \pm 106.8$ & $386.9 \pm 301.7$ & $96.2 \pm 229.7$ & $393.3 \pm 343.8$ & $77.5 \pm 71.8$ & $225.1 \pm 196.5$ & $90.8 \pm 131.9$ & $328.1 \pm 294.2$ \\
\hline
\end{tabular}

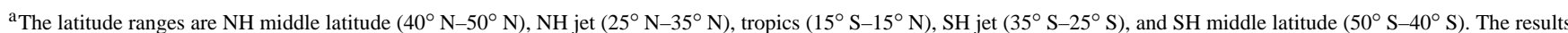
are shown in the format of the mean bias \pm RMS and defined as the CTM less Aura. The number of comparisons (N) is shown in Figs. 5 and 6 and the SEM values are generally about $1 \mathrm{ppb}$ and less than $3 \mathrm{ppb}$. TES* denotes the comparisons with the raw CTM outputs.
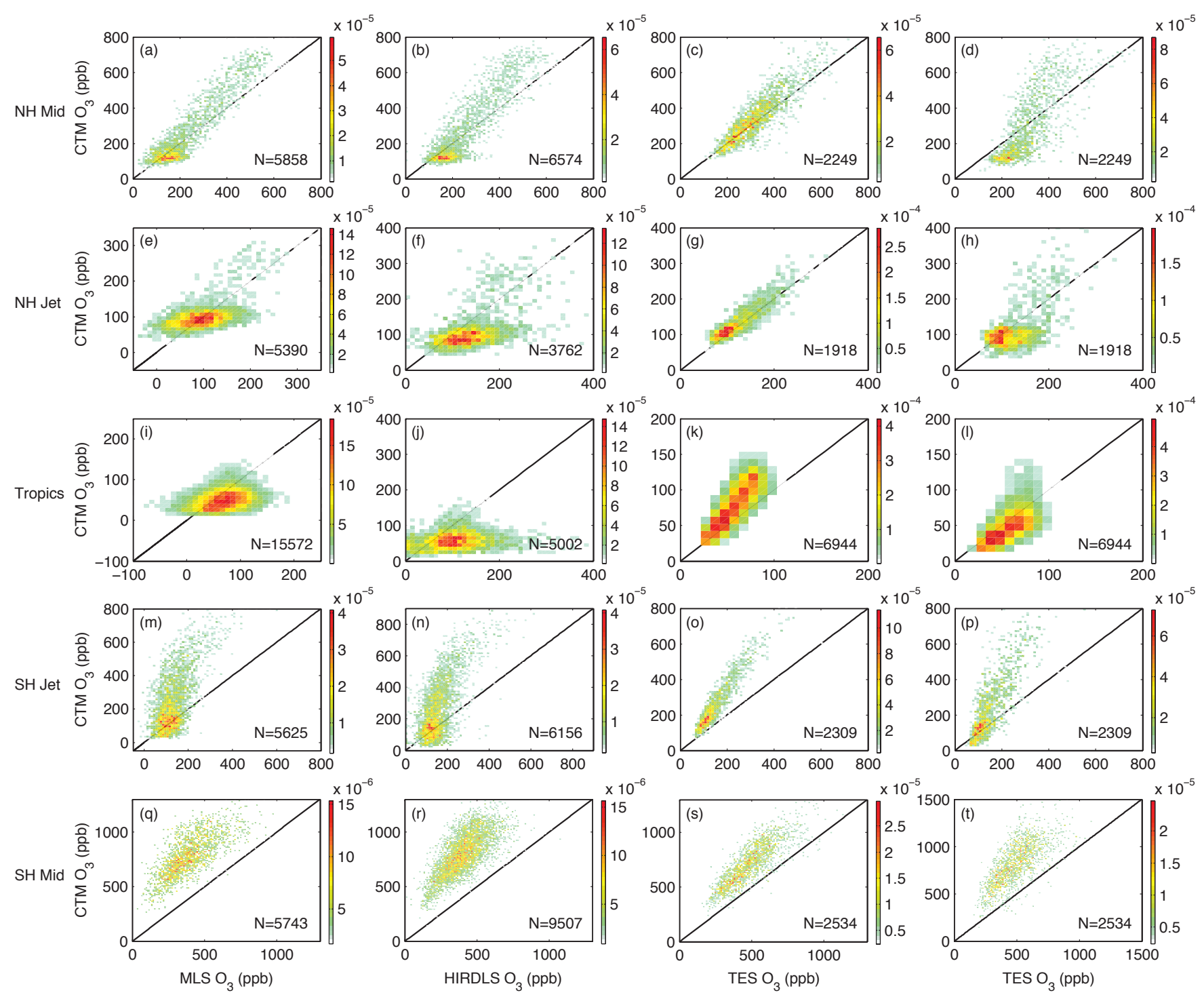

Fig. 6. Same as Fig. 5 for July 2005 at $147 \mathrm{hPa}$. 

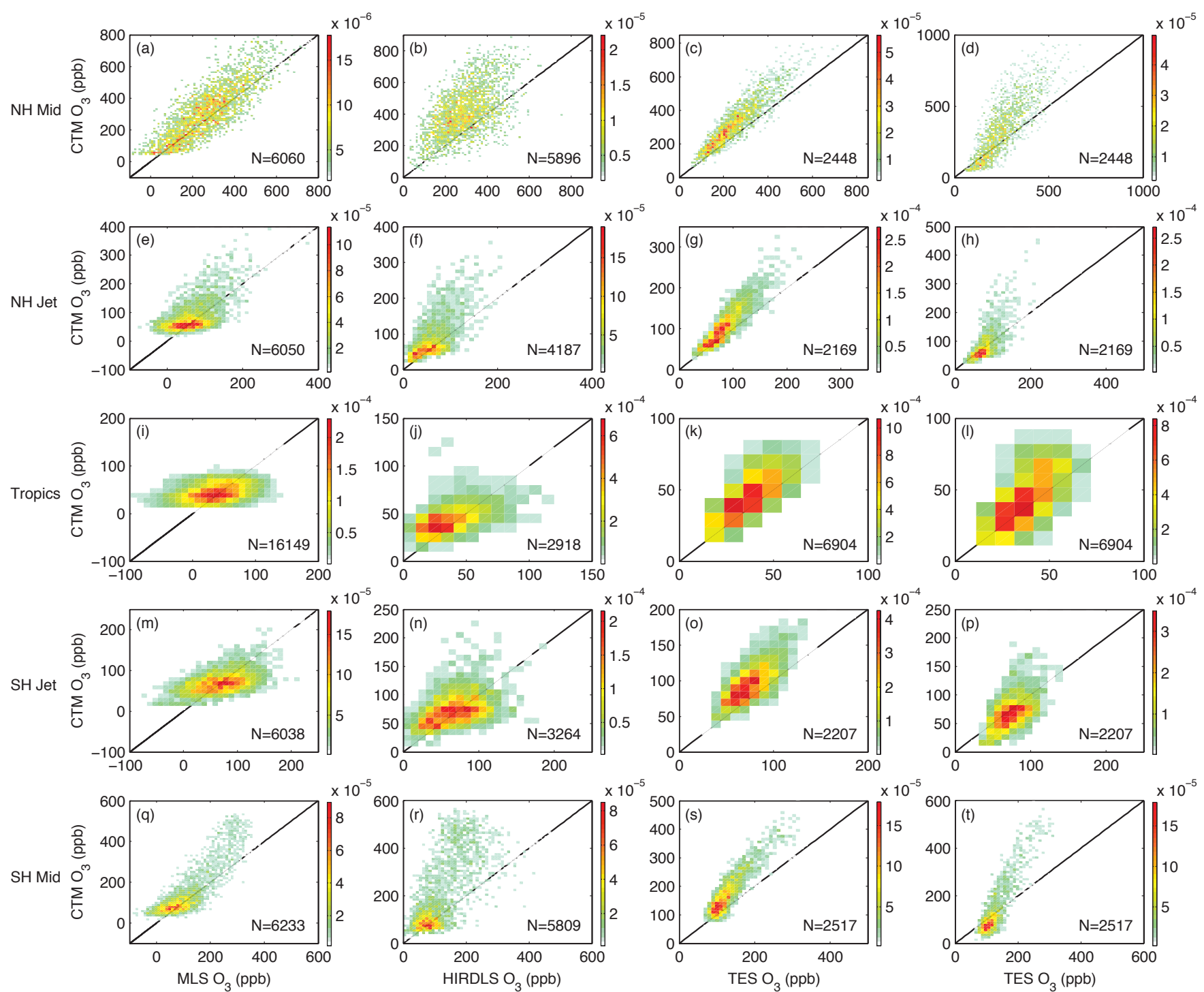

Fig. 7. Same as Fig. 5 for January 2006 at $215 \mathrm{hPa}$. The mean biases and RMS are given in Table 3.

Table 3. Same as Table 2 for January $2006^{\mathrm{a}}$.

\begin{tabular}{|c|c|c|c|c|c|c|c|c|}
\hline \multirow[b]{2}{*}{ Regions } & \multicolumn{2}{|c|}{ MLS } & \multicolumn{2}{|c|}{ HIRDLS } & \multicolumn{2}{|c|}{ TES } & \multicolumn{2}{|c|}{ TES* } \\
\hline & $215 \mathrm{hPa}$ & $147 \mathrm{hPa}$ & $215 \mathrm{hPa}$ & $147 \mathrm{hPa}$ & $215 \mathrm{hPa}$ & $147 \mathrm{hPa}$ & $215 \mathrm{hPa}$ & $147 \mathrm{hPa}$ \\
\hline NH Mid-L & $61.4 \pm 121.2$ & $344.1 \pm 257.7$ & $105.9 \pm 823.9$ & $344.8 \pm 288.2$ & $73.9 \pm 67.3$ & $155.3 \pm 111.4$ & $94.4 \pm 129.9$ & $331.6 \pm 297.7$ \\
\hline NH Jet & $37.0 \pm 77.0$ & $61.4 \pm 209.8$ & $52.3 \pm 94.4$ & $56.0 \pm 174.6$ & $30.7 \pm 39.6$ & $44.6 \pm 94.6$ & $33.8 \pm 86.1$ & $53.1 \pm 180.3$ \\
\hline Tropics & $11.0 \pm 66.4$ & $-13.2 \pm 242.5$ & $5.2 \pm 74.4$ & $-26.2 \pm 212.3$ & $8.4 \pm 40.4$ & $14.7 \pm 107.0$ & $7.1 \pm 68.2$ & $1.5 \pm 167.4$ \\
\hline SH Jet & $5.8 \pm 70.9$ & $37.3 \pm 201.0$ & $11.8 \pm 76.9$ & $13.0 \pm 187.0$ & $22.6 \pm 33.9$ & $61.7 \pm 76.4$ & $1.0 \pm 81.9$ & $5.1 \pm 178.9$ \\
\hline SH Mid-L & $49.4 \pm 79.3$ & $188.4 \pm 150.6$ & $87.9 \pm 138.7$ & $210.7 \pm 165.4$ & $54.7 \pm 45.9$ & $148.9 \pm 106.0$ & $37.9 \pm 96.9$ & $92.7 \pm 155.6$ \\
\hline
\end{tabular}

a The number of comparisons $(\mathrm{N})$ is shown in Figs. 7 and 8. 

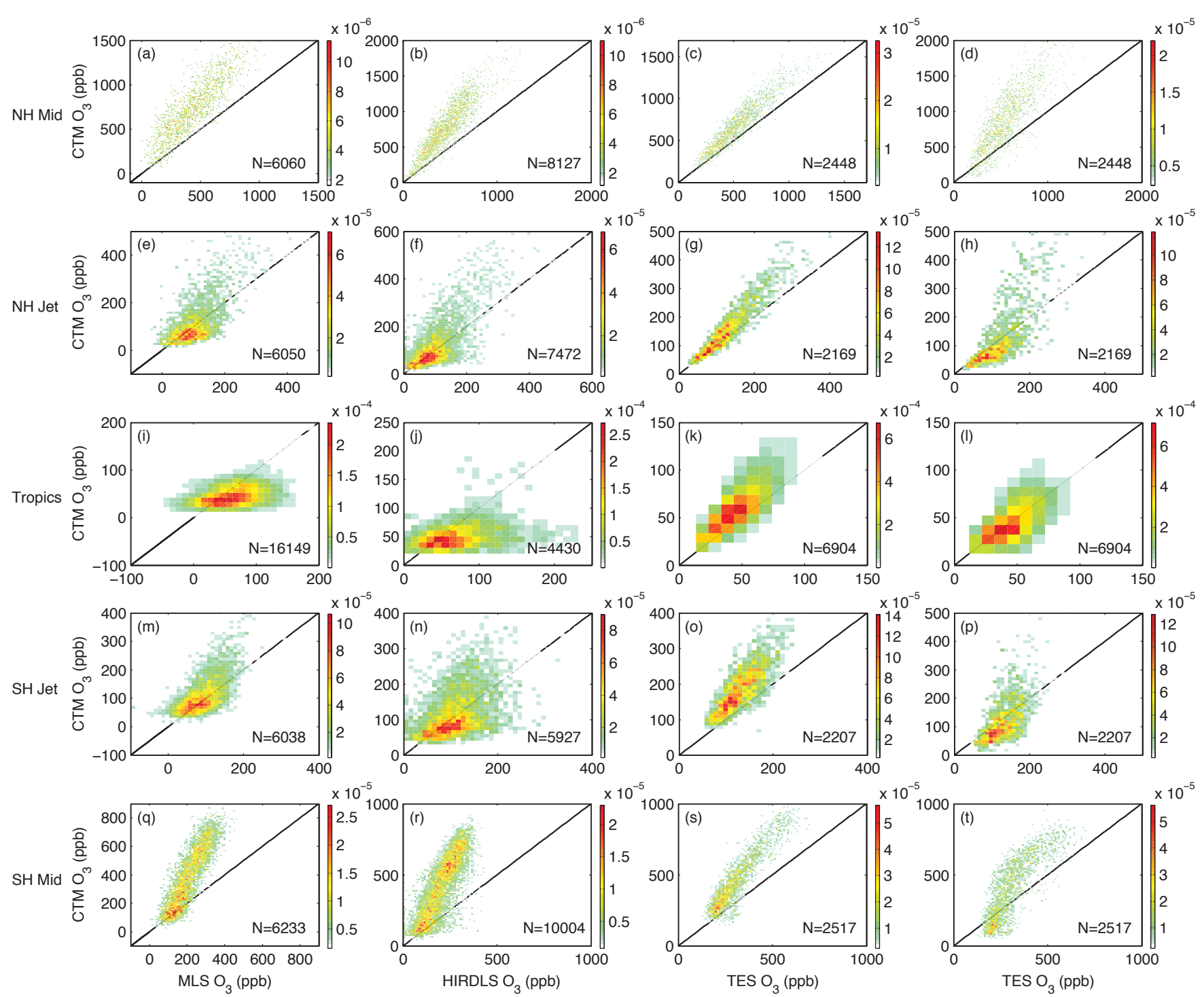

Fig. 8. Same as Fig. 5 for January 2006 at $147 \mathrm{hPa}$. The mean biases and RMS are given in Table 3 .

The red, high-density pixels are generally located close to the black solid, 1:1 line for all the three instruments, indicating small biases, except for stratospheric comparisons such as Fig. 6q-t. The CTM is generally biased high compared to all three Aura measurements in the lower stratosphere, suggesting a model deficiency that is most likely due to the errors in the stratospheric circulation of the 40-layer ECMWF meteorological fields previously noted (Hsu and Prather, 2009). As expected, TES gives generally tighter PDFs than MLS and HIRDLS, reflecting the differences between nadir and limb scanning. For tropospheric model values $(<100 \mathrm{ppb})$, such as in the tropics and jet regions of the summer hemisphere (Fig. 5e, f, i, j), the slopes of MLS and HIRDLS PDF are almost flat, consistent with low sensitivities and noise in the lowermost layers of these limb scanning measurements. Negative MLS profile values (e.g., Fig. 5a, q) are allowed in the retrieval algorithm to achieve the correct column loading (Livesey et al., 2007). The PDFs of HIRDLS are notably more dispersed compared to those of MLS and TES at $215 \mathrm{hPa}$ for the winter hemisphere middle latitudes (Fig. $5 \mathrm{r}$ and Fig. 7b), indicating greater noise in the HIRDLS measurements for this region and season. With the TES operator, the tropospheric CTM values $(<100 \mathrm{ppb})$ become stratospheric (>100 ppb) (e.g., Fig. 5c-d and Fig. 7s-t) as previously shown in Sect. 4.6. The CTM-TES comparisons are usually improved with application of the TES operator (e.g., Fig. $5 \mathrm{~g}-\mathrm{h}$ and Fig. $8 \mathrm{~g}-\mathrm{h}$ ) due to the relaxing towards the TES a priori and reducing the variance at a given pressure level by vertical smoothing (see Tables 2 and 3). Without some clear indication of the relative influence of the a prior in each retrieval, this CTM-TES agreement may be artificial. 
Tables 2 and 3 summarize the mean biases and root mean square (RMS) errors for Figs. 5-8. The RMS errors are generally much larger than the biases, consistent with previous validations against ozone sondes (Jiang et al., 2007; Nassar et al., 2008; Zhang et al., 2010), and are most likely due to the high variability at this pressure range for all latitude zones in both summer and winter. Note that the biases are less meaningful given such large RMS, and thus are only good for qualitative, long-term averages (i.e., L3 monthly gridded data). The biases clearly show that the CTM overestimates in subtropical jet and mid-latitude regions, again recognizing the model deficiency in these regions.

The results in Tables 2 and 3 identify inconsistencies among the Aura datasets. In July 2005 at $215 \mathrm{hPa}$, the CTM means are smaller than MLS and TES, while greater than HIRDLS in the tropics, NH jets, and mid-latitudes. Compared with sondes, TES has at most a $15 \%$ high bias in the troposphere (Nassar et al., 2008; Richards et al., 2008), while MLS has a $\sim 20 \%$ high bias at the middle to high-latitudes tropopause (Jiang et al., 2007). We have now shown that HIRDLS has large positive biases of $\sim 30-100 \mathrm{ppb}$ at $215 \mathrm{hPa}$ from the tropics to NH mid-latitudes in summer. In the tropics at $147 \mathrm{hPa}$, the CTM is smaller than MLS and HIRDLS but larger than TES for both July 2005 and January 2006, identifying a clear discrepancy between MLS-HIRDLS and TES without having to find collocated observations. In this case the RMS is much larger than the mean biases although the standard error of the mean (SEM) calculated assuming a normal distribution is smaller. The bias does not show in individual measurements, and the statistical significance of the bias in L3 gridded data depends greatly on the assumption of a normally distributed error that does not depend systematically on specific atmospheric conditions.

\section{Conclusions}

The high-resolution CTM $\left(1^{\circ} \times 1^{\circ} \times 40\right.$-layer $\left.\times 0.5 \mathrm{~h}\right)$ simulation of ozone reveals that the time scale of stratospheretroposphere exchange (STE) processes observed at a given location is as short as hours and indicates that STE occurs on a spatial scale of a few hundred kilometers. For nadirview instruments (e.g., OMI and TES), the application of their satellite operators (averaging kernel (AK) and a priori) can cause artificially high bias in the upper troposphere, as the nadir-view measurements have coarse vertical resolutions and their AK can smear the high $\mathrm{O}_{3}$ abundances in the stratosphere into the troposphere.
Aura without a fully functioning HIRDLS is not well designed for studying STE. The L2 swath data from Aura are chosen to study the STE flux of ozone based upon the shortlived features of most STE processes and previous case studies (Olsen et al., 2008; Manney et al., 2009; Pan et al., 2009; Manney et al., 2011). The high-resolution simulation with the UCI CTM depicts the full ozone picture for years 20052006 to compare with the individual, mostly non-coincident Aura ozone measurements derived from different remote sensing techniques. The model's ability to reproduce STErelated processes, such as tropospheric folds (TFs), is confirmed by the comparisons with the WOUDC sondes, giving confidence on the reliability and accuracy of the folding and intrusion structures simulated along Aura swaths.

From the eight case studies here, the four Aura instruments demonstrate some skill in catching the STE structures, either from the high TCO anomalies (for OMI) or from the $\mathrm{O}_{3}$ vertical profiles (for HIRDLS, MLS, and TES). Nevertheless, many of the features simulated by the model are not seen in the L2 data. Tropopause folds and stratospheric intrusions of $\mathrm{O}_{3}$ present a fundamental difficulty for satellite passive remote sensing due to large abundances and columns of stratospheric ozone above the troposphere. Beyond this work, Aura datasets have been studied for only a few STE cases, such as Pan et al. (2009); Manney et al. (2011). Improvements in the instruments and sensing techniques so as to greatly reduce the apparent noise in individual retrievals will be necessary if satellite observations are to be used to map out folds and intrusions on a regular basis and thus provide better constraint for the STE modeling.

We use the CTM as an intercomparison platform to investigate the consistency of different Aura ozone measurements that are close but not coincident in space, time, or averaging kernel. The CTM deficiencies can be readily identified when the biases are similar against all Aura observations. The 2-D PDF as well as the mean biases and RMS of exactly matched CTM-Aura data identifies the model's high biases in the lower stratosphere. On the other hand, the CTM as a transfer standard can be used to identify clearly the relative biases in the Aura ozone instruments on an instantaneous basis, including the meteorology at the time of observation, even when they do not have overlapping measurements. For example, the case study for July 2005 (Table 2) quantifies the different model-measurement biases for HIRDLS, MLS, and TES in the UT/LS region, thus identifying both consistencies and inconsistencies across these Aura datasets. 
Appendix A

Other case study results
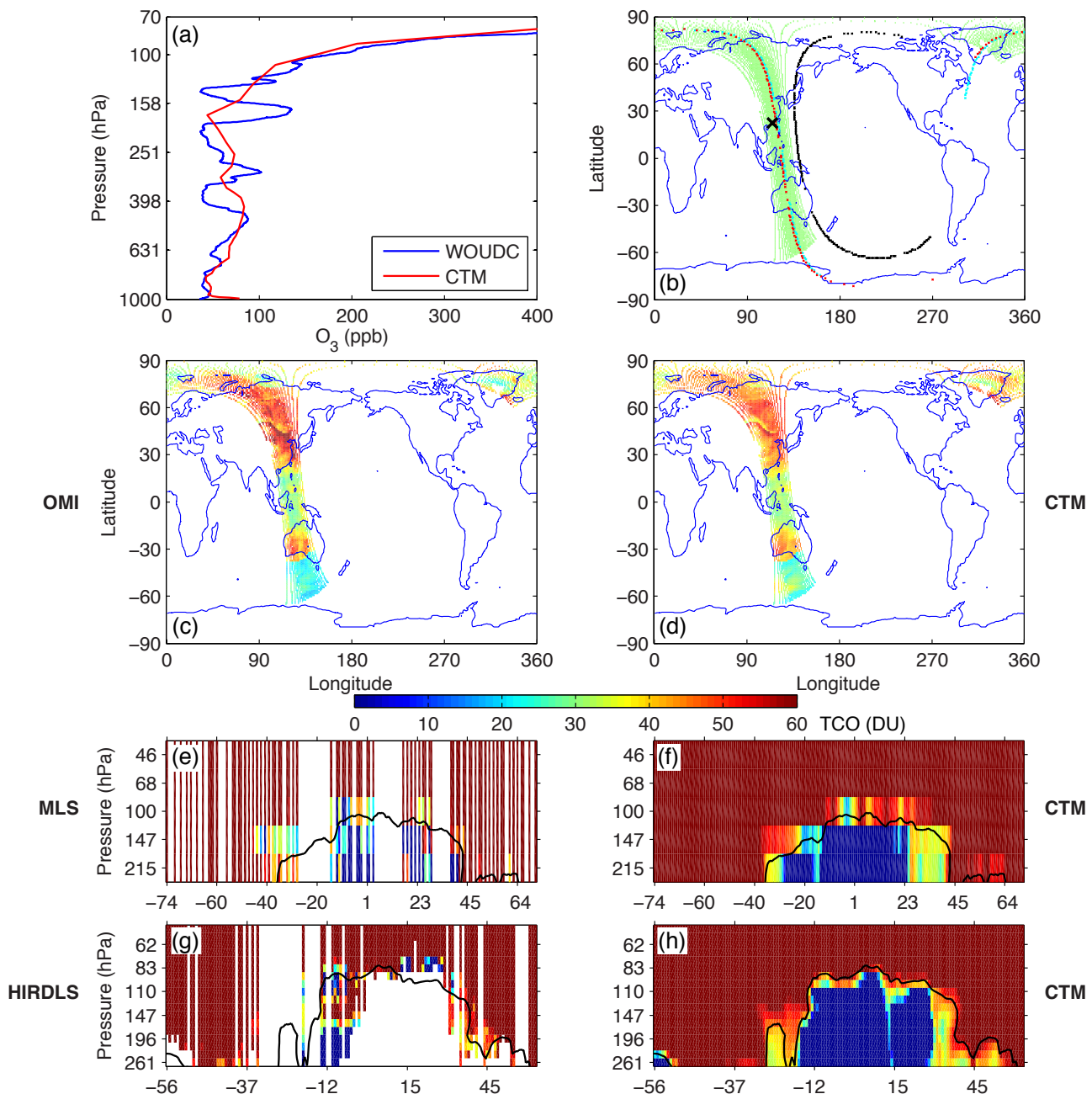

СтM

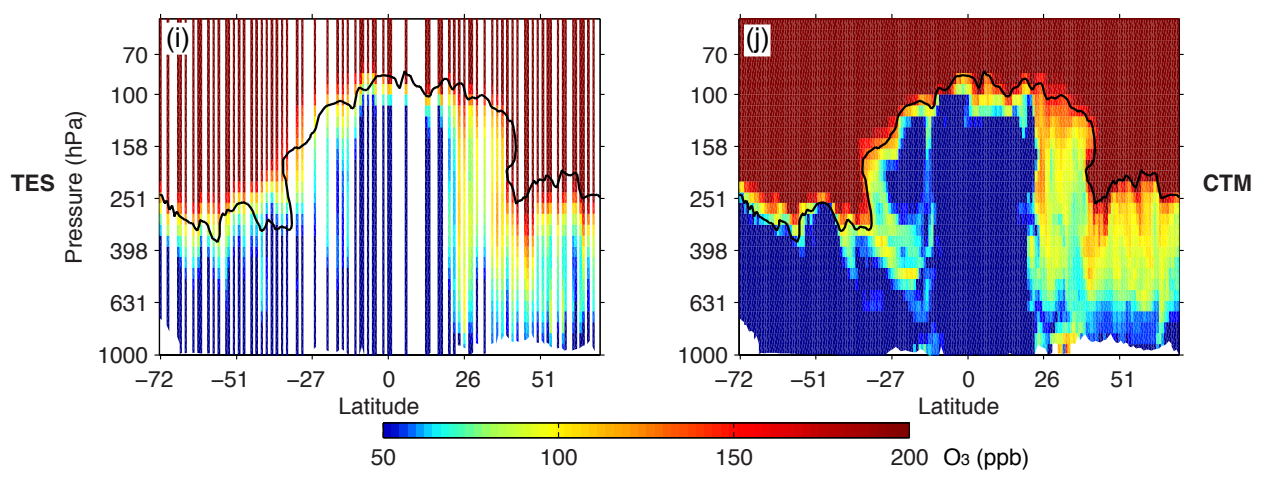

Fig. A1. Same as Fig. 3 for 27 July 2005. The sonde was measured at 05:22 UTC, compared with model simulation at 06:00 UTC in (a). The Aura and CTM swaths are for 05:00-06:00 UTC. (c)-(j) show the swaths in $0^{\circ}-180^{\circ} \mathrm{E}$. 

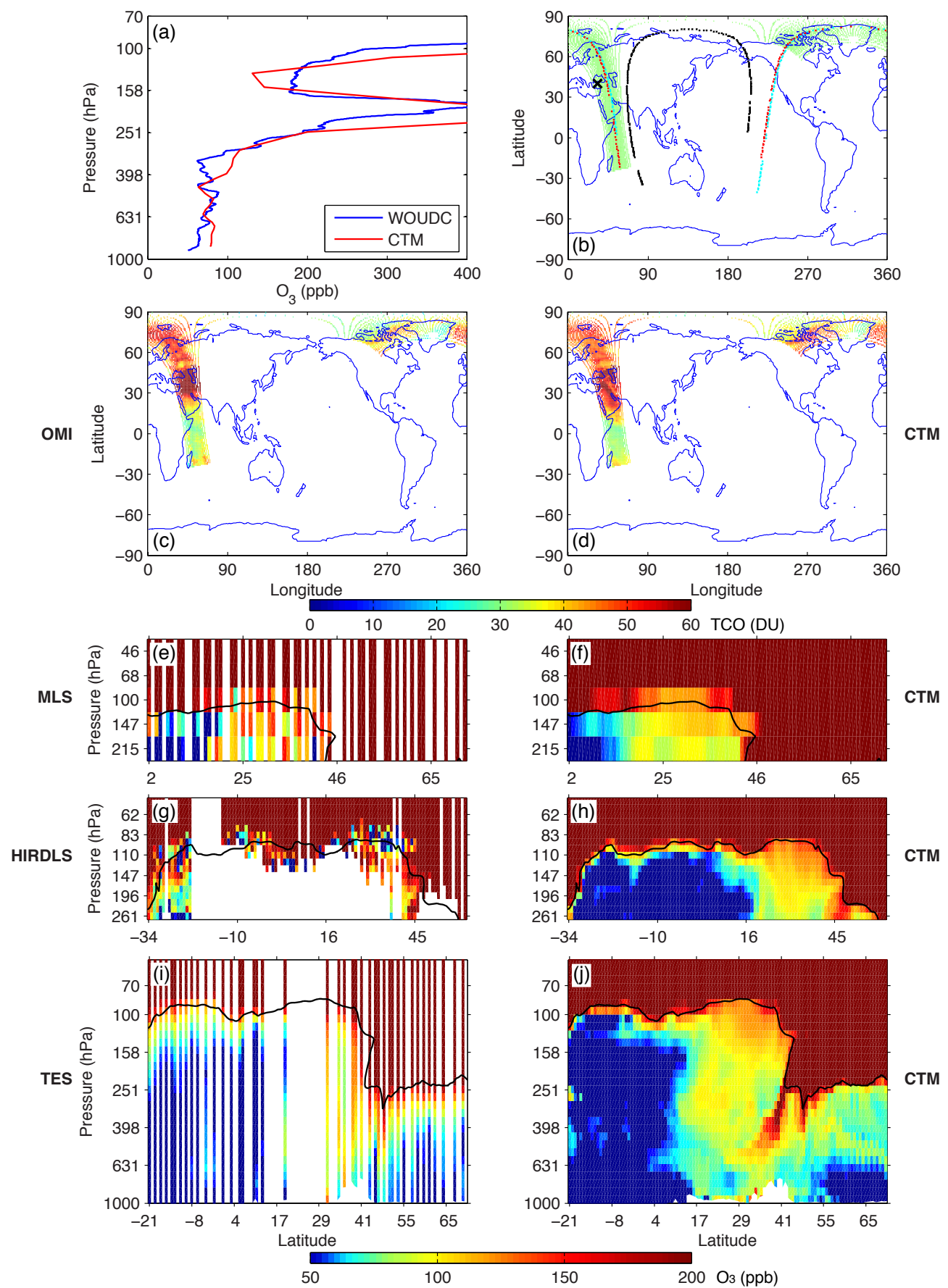

Fig. A2. Same as Fig. 3 for 6 July 2005. The sonde is from Ankara (40.0 N, 32.9 ${ }^{\circ}$ E, station code 348) at 11:52 UTC, compared with model simulation at 12:00 UTC in (a). The Aura and CTM swaths are for 10:00-11:00 UTC. (c)-(j) show the swaths in $0^{\circ}-134^{\circ} \mathrm{E}$. 

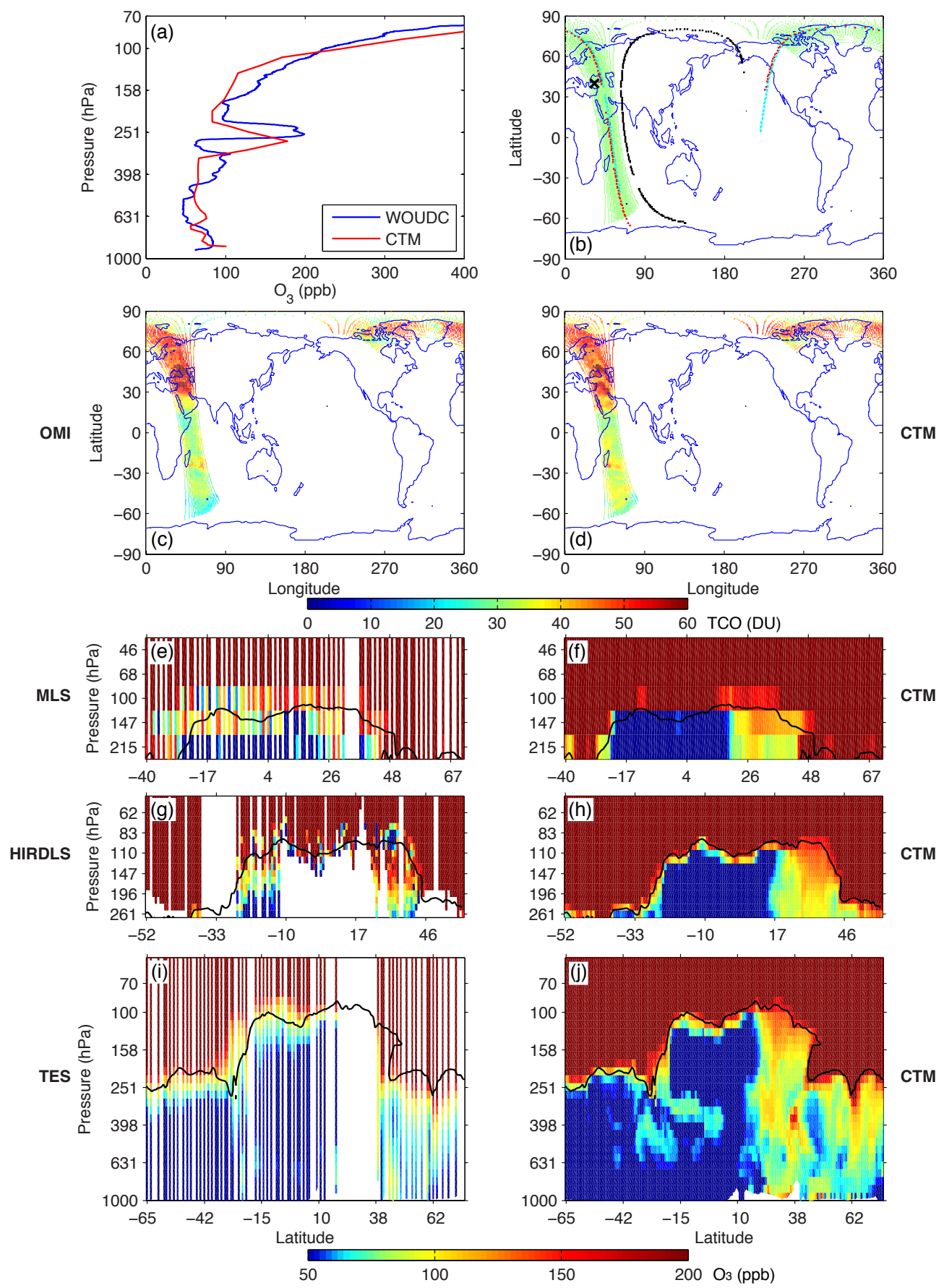

Fig. A3. Same as Fig. A2 for 20 July 2005. The sonde was measured at 11:37 UTC, compared with model simulation at 12:00 UTC in (a). The Aura and CTM swaths are for 10:00-11:00 UTC. (c)-(j) show the swaths in $0^{\circ}-99^{\circ} \mathrm{E}$. 

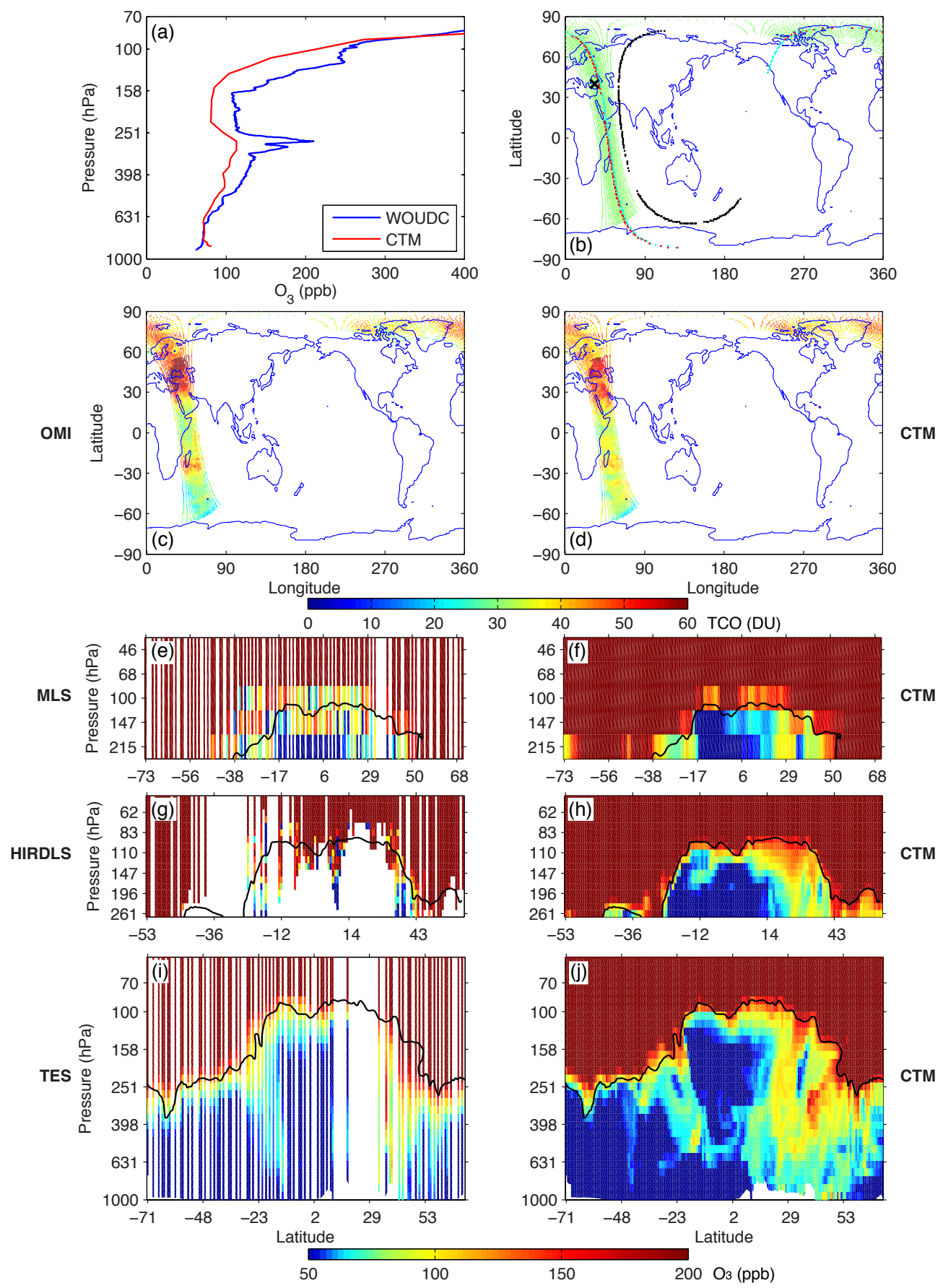

Fig. A4. Same as Fig. A2 for 3 August 2005. The sonde was measured at 11:36 UTC. 

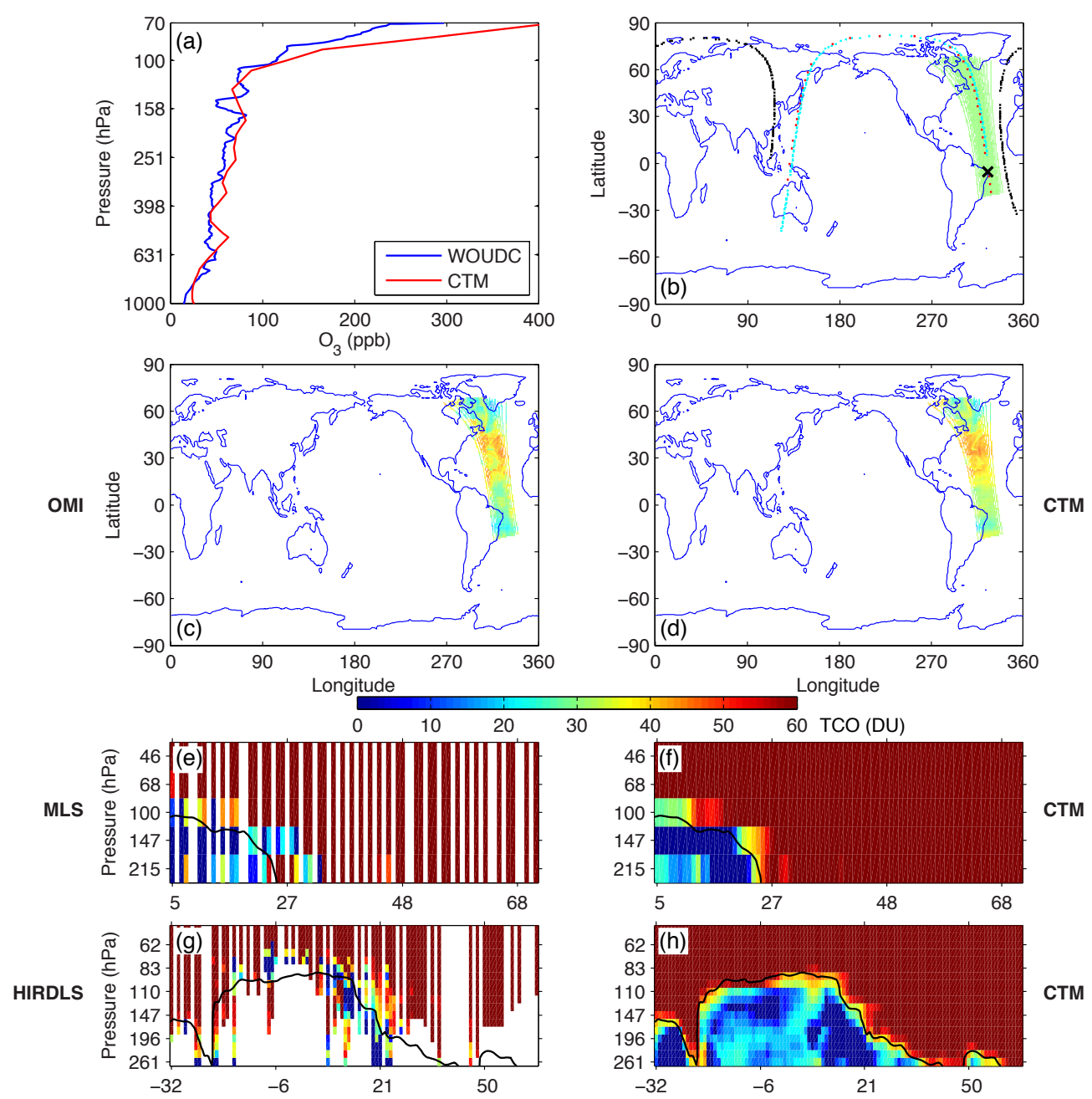

Стм

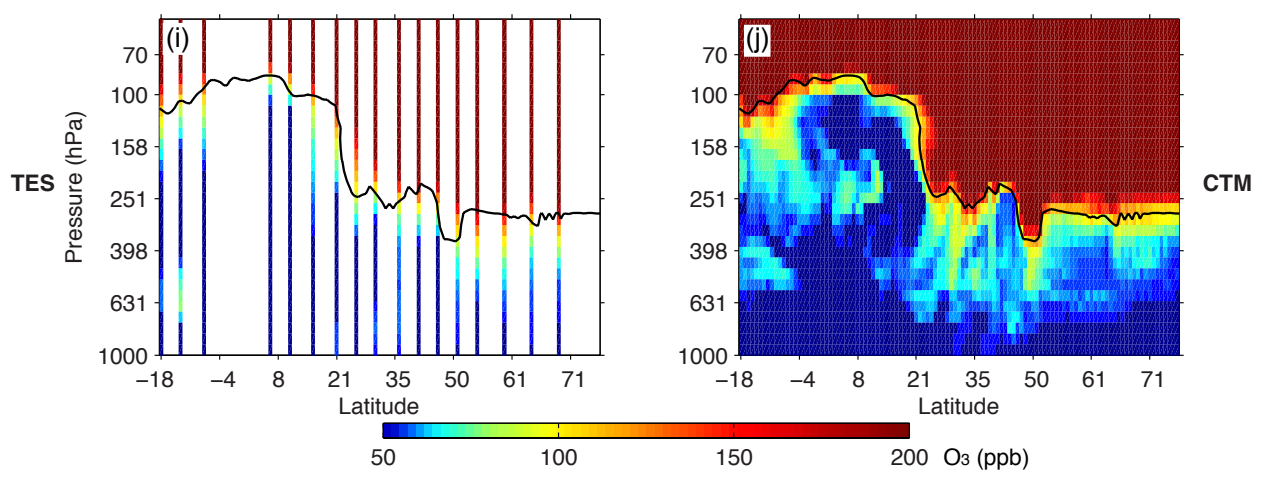

Fig. A5. Same as Fig. 3 for 2 February 2005. The sonde is from Maxaranguape $\left(5.4^{\circ} \mathrm{S}, 35.4^{\circ} \mathrm{W}\right.$, station code 466$)$ at $15: 45 \mathrm{UTC}$, compared with model simulation at 16:00 UTC in (a). The Aura and CTM swaths are for 16:00-17:00 UTC. (c)-(j) show the swaths in $251^{\circ} \mathrm{E}-360^{\circ} \mathrm{E}$. 

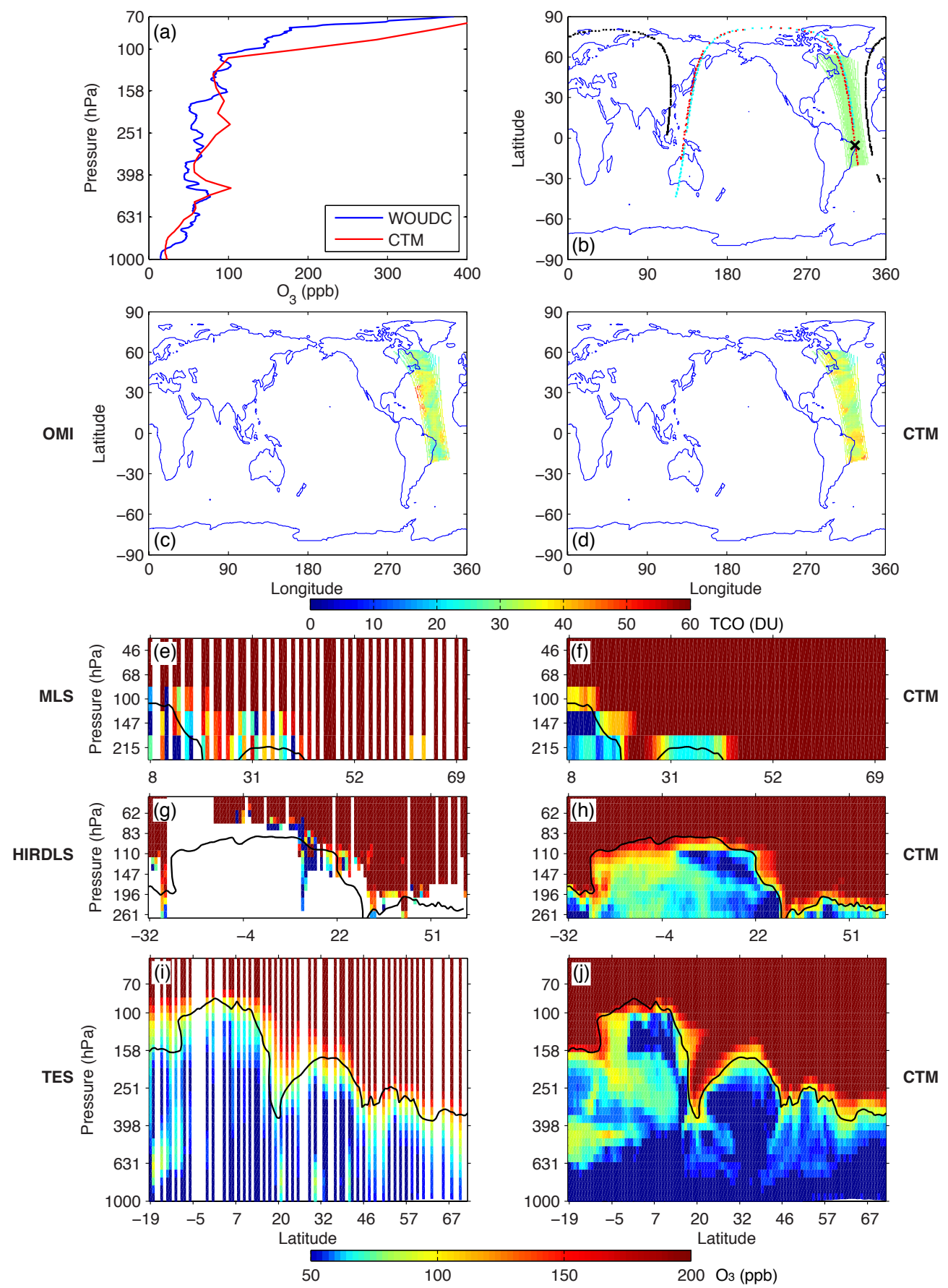

Fig. A6. Same as Fig. A5 for 19 December 2005. The sonde was measured at 16:00 UTC. 

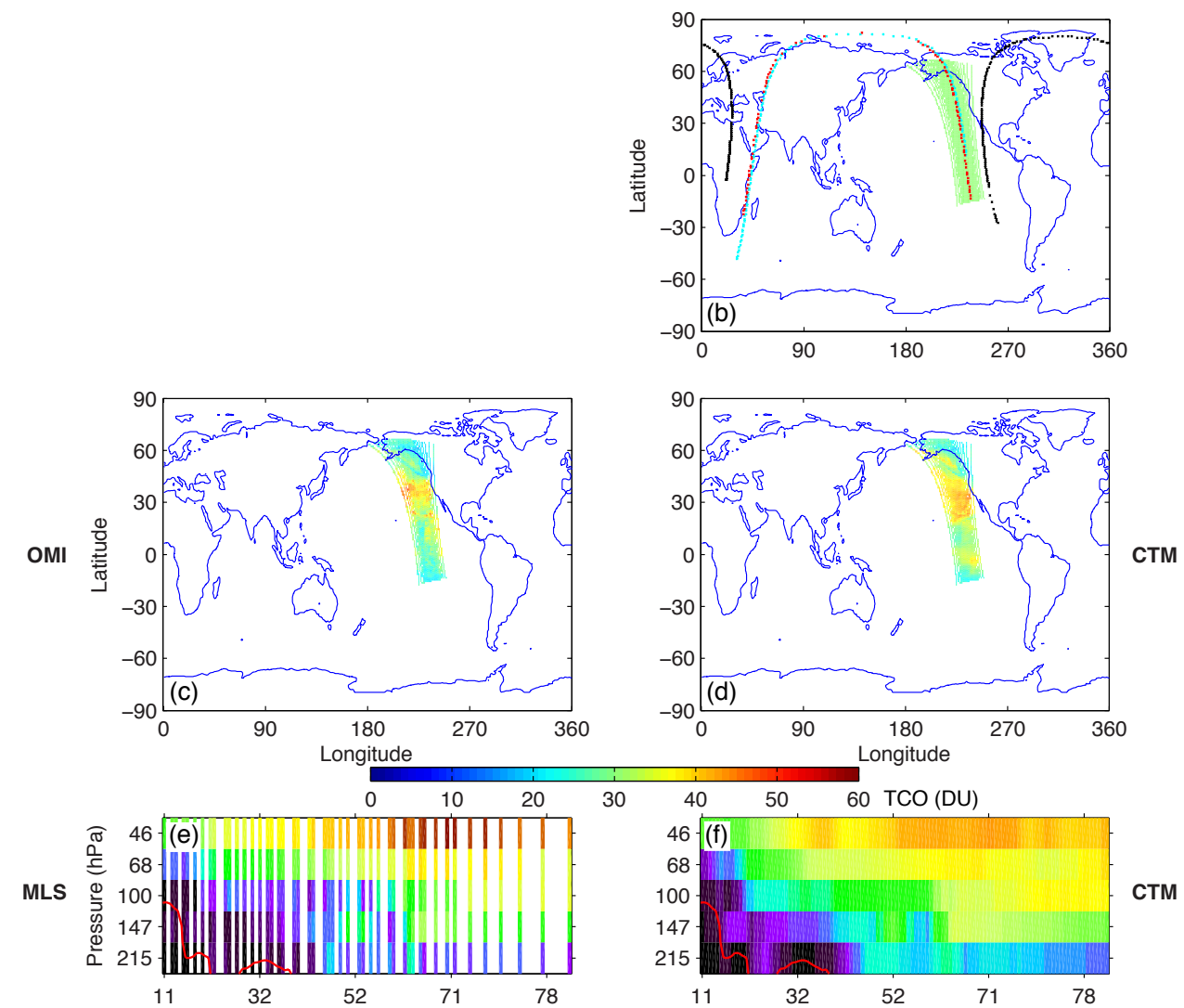

СтM
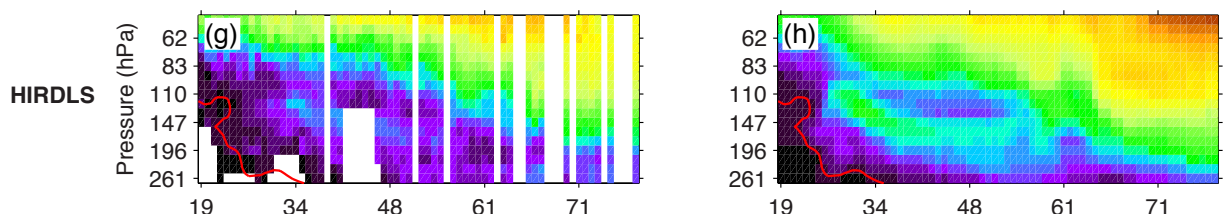

стм

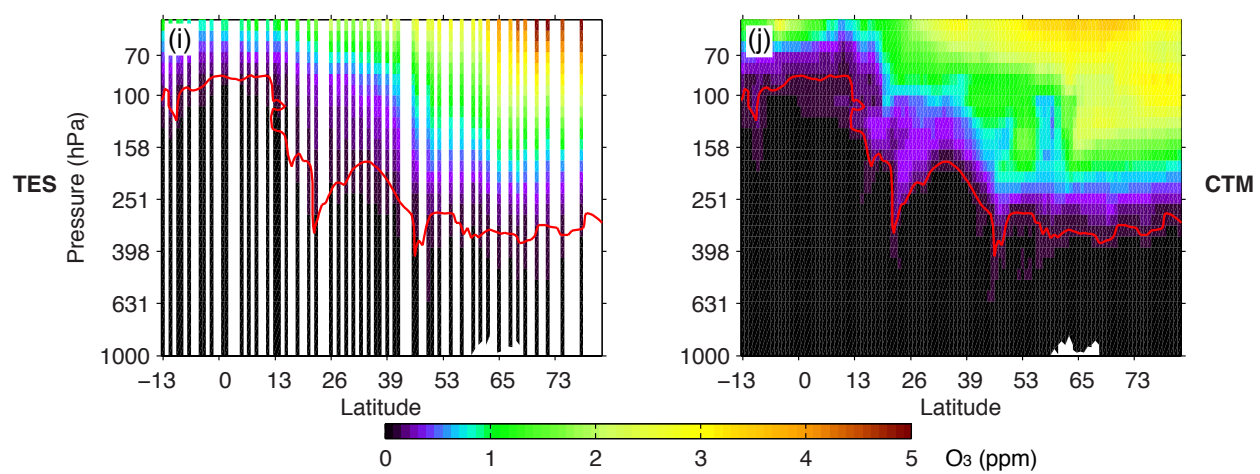

Fig. A7. Same as Fig. 3 for 26 January 2006 except that no sonde is available and the e90 tropopause is indicated by red solid lines in (e)-(j). The Aura and CTM swaths are for 22:00-23:00 UTC. (c)-(j) show the swaths in $181^{\circ} \mathrm{E}-270^{\circ} \mathrm{E}$. (g) and (h) only show the HIRDLS swath at $19^{\circ} \mathrm{N}-74^{\circ} \mathrm{N}$ to mimic the Fig. 1 of Olsen et al. (2008). 
Acknowledgements. The authors thank Anne Douglass and anonymous reviewers for their careful, detailed review and constructive suggestions. This work is funded by NASA grant (NNX08AR25G) to UCI and NSF grant (AGS-1042787) to Cornell University.

Edited by: D. Shindell

\section{References}

Alexander, M. J., Gille, J., Cavanaugh, C., Coffey, M., Craig, C., Eden, T., Francis, G., Halvorson, C., Hannigan, J., Khosravi, R., Kinnison, D., Lee, H., Massie, S., Nardi, B., Barnett, J., Hepplewhite, C., Lambert, A., and Dean, V.: Global estimates of gravity wave momentum flux from High Resolution Dynamics Limb Sounder observations, J. Geophys. Res., 113, D15S18, doi:10.1029/2007JD008807, 2008.

Atkinson, R. and Arey, J.: Gas-phase tropospheric chemistry of biogenic volatile organic compounds: a review, Atmos. Environ., 37, 197-219, doi:10.1016/S1352-2310(03)00391-1, 2003.

Carver, G., Brown, P., and Wild, O.: The ASAD atmospheric chemistry integration package and chemical reaction database, Comput. Phys. Commun., 105, 197-215, 1997.

Danielsen, E. F.: Stratospheric-tropospheric exchange based on radioactivity, ozone and potential vorticity, J. Atmos. Sci., 25, 502518, 1968.

de Haan, J. F. and Veefkind, J. P.: OMO3PR Readme, http://disc.sci.gsfc.nasa.gov/Aura/data-holdings/OMI/ documents/v003/OMO3PRO_README.html, 2009.

Denman, K. L., Brasseur, G., Chidthaisong, A., Ciais, P., Cox, P. M., Dickinson, R. E., Hauglustaine, D., Heinze, C., Holland, E., Jacob, D., Lohmann, U., Ramachandran, S., da Silva Dias, P. L., Wofsy, S. C., and Zhang, X.: Couplings Between Changes in the Climate System and Biogeochemistry, in: Climate Change 2007: The Physical Science Basis. Contribution of Working Group I to the Fourth Assessment Report of the Intergovernmental Panel on Climate Change, edited by Solomon, S., Qin, D., Manning, M., Chen, Z., Marquis, M., Averyt, K. B., Tignor, M., and Miller, H. L., chap. 7, pp. 499-587, Cambridge University Press, Cambridge, United Kingdom and New York, NY, USA, 2007.

Fusco, A. C. and Logan, J. A.: Analysis of 1970-1995 trends in tropospheric ozone at Northern Hemisphere midlatitudes with the GEOS-CHEM model, J. Geophys. Res., 108, 4449, doi:10.1029/2002JD002742, 2003.

Gauss, M., Myhre, G., Isaksen, I. S. A., Grewe, V., Pitari, G., Wild, O., Collins, W. J., Dentener, F. J., Ellingsen, K., Gohar, L. K., Hauglustaine, D. A., Iachetti, D., Lamarque, F., Mancini, E., Mickley, L. J., Prather, M. J., Pyle, J. A., Sanderson, M. G., Shine, K. P., Stevenson, D. S., Sudo, K., Szopa, S., and Zeng, G.: Radiative forcing since preindustrial times due to ozone change in the troposphere and the lower stratosphere, Atmos. Chem. Phys., 6, 575-599, doi:10.5194/acp-6-575-2006, 2006.

Gettelman, A., Holton, J. R., and Rosenlof, K. H.: Mass fluxes of $\mathrm{O}_{3}, \mathrm{CH}_{4}, \mathrm{~N}_{2} \mathrm{O}$ and $\mathrm{CF}_{2} \mathrm{Cl}_{2}$ in the lower stratosphere calculated from observational data, J. Geophys. Res., 102, 19149-19159, doi:10.1029/97JD01014, 1997.

HIRDLS Team: High Resolution Dynamics Limb Sounder Earth Observing System (EOS) Data Description and Qual- ity Version 5 (V5), http://disc.sci.gsfc.nasa.gov/Aura/dataholdings/HIRDLS/documents/HIRDLS-V5-DQD-

6May2010.pdf, last access: 10 May 2010, 2010.

Holmes, C. D., Tang, Q., and Prather, M. J.: Uncertainties in climate assessment for the case of aviation NO, P. Natl. Acad. Sci. U.S.A., 108, 10 997-11 002, doi:10.1073/pnas.1101458108, 2011.

Hoor, P., Borken-Kleefeld, J., Caro, D., Dessens, O., Endresen, O., Gauss, M., Grewe, V., Hauglustaine, D., Isaksen, I. S. A., Jöckel, P., Lelieveld, J., Myhre, G., Meijer, E., Olivie, D., Prather, M., Schnadt Poberaj, C., Shine, K. P., Staehelin, J., Tang, Q., van Aardenne, J., van Velthoven, P., and Sausen, R.: The impact of traffic emissions on atmospheric ozone and $\mathrm{OH}$ : results from QUANTIFY, Atmos. Chem. Phys., 9, 3113-3136, doi:10.5194/acp-9-3113-2009, 2009.

Hsu, J. and Prather, M. J.: Stratospheric variability and tropospheric ozone, J. Geophys. Res., 114, D06102, doi:10.1029/2008JD010942, 2009.

Hsu, J., Prather, M. J., and Wild, O.: Diagnosing the stratosphereto-troposphere flux of ozone in a chemistry transport model, J. Geophys. Res., 110, D19305, doi:10.1029/2005JD006045, 2005.

Isaksen, I. S. A., Zerefos, C., Kourtidis, K., Meleti, C., Dalsoren, S. B., Sundet, J. K., Grini, A., Zanis, P., and Balis, D.: Tropospheric ozone changes at unpolluted and semipolluted regions induced by stratospheric ozone changes, J. Geophys. Res., 110, D02302, doi:10.1029/2004JD004618, 2005.

Jiang, Y. B., Froidevaux, L., Lambert, A., Livesey, N. J., Read, W. G., Waters, J. W., Bojkov, B., Leblanc, T., McDermid, I. S., Godin-Beekmann, S., Filipiak, M. J., Harwood, R. S., Fuller, R. A., Daffer, W. H., Drouin, B. J., Cofield, R. E., Cuddy, D. T., Jarnot, R. F., Knosp, B. W., Perun, V. S., Schwartz, M. J., Snyder, W. V., Stek, P. C., Thurstans, R. P., Wagner, P. A., Allaart, M., Andersen, S. B., Bodeker, G., Calpini, B., Claude, H., Coetzee, G., Davies, J., Backer, H. D., Dier, H., Fujiwara, M., Johnson, B., Kelder, H., Leme, N. P., König-Langlo, G., Kyro, E., Laneve, G., Fook, L. S., Merrill, J., Morris, G., Newchurch, M., Oltmans, S., Parrondos, M. C., Posny, F., Schmidlin, F., Skrivankova, P., Stubi, R., Tarasick, D., Thompson, A., Thouret, V., Viatte, P., Vömel, H., von Der Gathen, P., Yela, M., and Zablocki, G.: Validation of Aura Microwave Limb Sounder Ozone by ozonesonde and lidar measurements, J. Geophys. Res., 112, D24S34, doi:10.1029/2007JD008776, 2007.

Kraabøl, A. G., Berntsen, T. K., Sundet, J. K., and Stordal, F.: Impacts of $\mathrm{NO}_{\mathrm{x}}$ emissions from subsonic aircraft in a global three-dimensional chemistry transport model including plume processes, J. Geophys. Res., 107, 4655, doi:10.1029/2001JD001019, 2002.

Lacis, A. A., Wuebbles, D. J., and Logan, J. A.: Radiative Forcing of Climate by Changes in the Vertical Distribution of Ozone, J. Geophys. Res., 95, 9971-9981, doi:10.1029/JD095iD07p09971, 1990.

Livesey, N. J., Read, W. G., Lambert, A., Cofield, R. E., Cuddy, D. T., Froidevaux, L., Fuller, R. A., Jarnot, R. F., Jiang, J. H., Jiang, Y. B., Knosp, B. W., Kovalenko, L. J., Pickett, H. M., Pumphrey, H. C., Santee, M. L., Schwartz, M. J., Stek, P. C., Wagner, P. A., Waters, J. W., and Wu, D. L.: Earth Observing System (EOS) Aura Microwave Limb Sounder (MLS) Version 2.2 Level 2 data quality and description document, Tech. Rep. D-33509, JPL, Jet Propulsion Laboratory California Institute of 
Technology Pasadena, California, 91109-8099, 2007.

Livesey, N. J., Read, W. G., Froidevaux, L., Lambert, A., Manney, G. L., Pumphrey, H. C., Santee, M. L., Schwartz, M. J., Wang, S., Cofield, R. E., Cuddy, D. T., Fuller, R. A., Jarnot, R. F., Jiang, J. H., Knosp, B. W., Stek, P. C., Wagner, P. A., and Wu, D. L.: Earth Observing System (EOS) Aura Microwave Limb Sounder (MLS) Version 3.3 Level 2 data quality and description document, Tech. Rep. D-33509, JPL, Jet Propulsion Laboratory California Institute of Technology Pasadena, California, 911098099, 2011.

Luo, M., Rinsland, C., Fisher, B., Sachse, G., Diskin, G., Logan, J., Worden, H., Kulawik, S., Osterman, G., Eldering, A., Herman, R., and Shephard, M.: TES carbon monoxide validation with DACOM aircraft measurements during INTEX-B 2006, J. Geophys. Res., 112, D24S48, doi:10.1029/2007JD008803, 2007.

Manney, G. L., Harwood, R. S., MacKenzie, I. A., Minschwaner, K., Allen, D. R., Santee, M. L., Walker, K. A., Hegglin, M. I., Lambert, A., Pumphrey, H. C., Bernath, P. F., Boone, C. D., Schwartz, M. J., Livesey, N. J., Daffer, W. H., and Fuller, R. A.: Satellite observations and modeling of transport in the upper troposphere through the lower mesosphere during the 2006 major stratospheric sudden warming, Atmos. Chem. Phys., 9, 47754795, doi:10.5194/acp-9-4775-2009, 2009.

Manney, G. L., Hegglin, M. I., Daffer, W. H., Santee, M. L., Ray, E. A., Pawson, S., Schwartz, M. J., Boone, C. D., Froidevaux, L., Livesey, N. J., Read, W. G., and Walker, K. A.: Jet characterization in the upper troposphere/lower stratosphere (UTLS): applications to climatology and transport studies, Atmos. Chem. Phys., 11, 6115-6137, 2011,

http://www.atmos-chem-phys.net/11/6115/2011/.

Murphy, D. M. and Fahey, D. W.: An estimate of the flux of stratospheric reactive nitrogen and ozone into the troposphere, J. Geophys. Res., 99, 5325-5332, http://dx.doi.org/10.1029/93JD03558, 1994.

Myhre, G., Shine, K. P., Rädel, G., Gauss, M., Isaksen, I. S. A., Tang, Q., Prather, M. J., Williams, J. E., van Velthoven, P., Dessens, O., Koffi, B., Szopa, S., Hoor, P., Grewe, V., Borken-Kleefeld, J., Berntsen, T. K., and Fuglestvedt, J. S.: Radiative forcing due to changes in ozone and methane caused by the transport sector, Atmos. Environ., 45, 387-394, doi:10.1016/j.atmosenv.2010.10.001, 2011.

Nassar, R., Logan, J. A., Worden, H. M., Megretskaia, I. A., Bowman, K. W., Osterman, G. B., Thompson, A. M., Tarasick, D. W., Austin, S., Claude, H., Dubey, M. K., Hocking, W. K., Johnson, B. J., Joseph, E., Merrill, J., Morris, G. A., Newchurch, M., Oltmans, S. J., Posny, F., Schmidlin, F. J., Vömel, H., Whiteman, D. N., and Witte, J. C.: Validation of Tropospheric Emission Spectrometer (TES) nadir ozone profiles using ozonesonde measurements, J. Geophys. Res., 113, D15S17, doi:10.1029/2007JD008819, 2008.

Olsen, M. A., Schoeberl, M. R., and Douglass, A. R.: Stratospheretroposphere exchange of mass and ozone, J. Geophys. Res., 109, D24114, doi:10.1029/2004JD005186, 2004.

Olsen, M. A., Douglass, A. R., Newman, P. A., Gille, J. C., Nardi, B., Yudin, V. A., Kinnison, D. E., and Khosravi, R.: HIRDLS observations and simulation of a lower stratospheric intrusion of tropical air to high latitudes, Geophys. Res. Lett., 35, L21813, doi:10.1029/2008GL035514, 2008.

Olsen, S. C., McLinden, C. A., and Prather, M. J.: Stratospheric
$\mathrm{N}_{2} \mathrm{O}-\mathrm{NO}_{\mathrm{y}}$ system: Testing uncertainties in a three-dimensional framework, J. Geophys. Res., 106, 28771-28784, 2001.

OMI Team: Ozone Monitoring Instrument (OMI) Data User's Guide, OMI-DUG-3.0, http://disc.sci.gsfc.nasa.gov/Aura/ additional/documentation/README.OMI_DUG.pdf, last access: 4 August 2010, 2009.

Osterman, G. B., Kulawik, S. S., Worden, H. M., Richards, N. A. D., Fisher, B. M., Eldering, A., Shephard, M. W., Froidevaux, L., Labow, G., Luo, M., Herman, R. L., Bowman, K. W., and Thompson, A. M.: Validation of Tropospheric Emission Spectrometer (TES) measurements of the total, stratospheric, and tropospheric column abundance of ozone, J. Geophys. Res., 113, D15S16, doi:10.1029/2007JD008801, 2008.

Osterman, G., Bowman, K., Eldering, A., Fisher, B., Herman, R., Jacob, D., Jourdain, L., Kulawik, S., Luo, M., Monarrez, R., Paradise, S., Payne, V., Poosti, S., Richards, N., Rider, D., Shepard, D., Shephard, M., Vilnrotter, F., Worden, H., Worden, J., Yun, H., and Zhang, L.: Earth Observing System (EOS) Tropospheric Emission Spectrometer (TES) Level 2 (L2) Data User's Guide (Up to \& including Version 4 data), Tech. Rep. D-38042, Version 4.0, JPL, Jet Propulsion Laboratory California Institute of Technology Pasadena, California, 91109-8099, 2009.

Pan, L. L., Randel, W. J., Gille, J. C., Hall, W. D., Nardi, B., Massie, S., Yudin, V., Khosravi, R., Konopka, P., and Tarasick, D.: Tropospheric intrusions associated with the secondary tropopause, J. Geophys. Res., 114, D10302, doi:10.1029/2008JD011374, 2009.

Prather, M. J.: Numerical advection by conservation of secondorder moments, J. Geophys. Res., 91, 6671-6681, 1986.

Prather, M. J., Zhu, X., Tang, Q., Hsu, J., and Neu, J. L.: An atmospheric chemist in search of the tropopause, J. Geophys. Res., 116, D04306, doi:10.1029/2010JD014939, 2011.

Richards, N. A. D., Osterman, G. B., Browell, E. V., Hair, J. W., Avery, M., and Li, Q.: Validation of Tropospheric Emission Spectrometer ozone profiles with aircraft observations during the Intercontinental Chemical Transport Experiment-B, J. Geophys. Res., 113, D16S29, doi:10.1029/2007JD008815, 2008.

Roelofs, G. J. and Lelieveld, J.: Model study of the influence of cross-tropopause $\mathrm{O}_{3}$ transports on tropospheric $\mathrm{O}_{3}$ levels, Tellus B, 49, 38-55, 1997.

Sander, S. P., Friedl, R. R., Golden, D. M., Kurylo, M. J., Moortgat, G. K., Keller-Rudek, H., Wine, P. H., Ravishankara, A. R., Kolb, C. E., Molina, M. J., Finlayson-Pitts, B. J., Huie, R. E., and Orkin, V. L.: Chemical Kinetics and Photochemical Data for Use in Atmospheric Studies, JPL Publication 06-2, NASA/JPL, Jet Propulsion Laboratory, California Institute of Technology, Pasadena, California, Evaluation Number 15, 2006.

Schoeberl, M. R., Douglass, A. R., Hilsenrath, E., Bhartia, P. K., Beer, R., Waters, J. W., Gunson, M. R., Froidevaux, L., Gille, J. C., Barnett, J. J., Levelt, P. F., and DeCola, P.: Overview of the EOS Aura Mission, IEEE Trans. Geosci. Remote Sens., 44, 1066-1074, doi:10.1109/TGRS.2005.861950, 2006.

Shao, M., Lu, S., Liu, Y., Xie, X., Chang, C., Huang, S., and Chen, Z.: Volatile organic compounds measured in summer in Beijing and their role in ground-level ozone formation, J. Geophys. Res., 114, D00G06, doi:10.1029/2008JD010863, 2009.

Tang, Q. and Prather, M. J.: Correlating tropospheric column ozone with tropopause folds: the Aura-OMI satellite data, Atmos. Chem. Phys., 10, 9681-9688, doi:10.5194/acp-10-9681-2010, 2010. 
Tang, Q., Prather, M. J., and Hsu, J.: Stratosphere-troposphere exchange ozone flux related to deep convection, Geophys. Res. Lett., 38, L03806, doi:10.1029/2010GL046039, 2011.

Terao, Y., Logan, J. A., Douglass, A. R., and Stolarski, R. S.: Contribution of stratospheric ozone to the interannual variability of tropospheric ozone in the northern extratropics, J. Geophys. Res., 113, doi:10.1029/2008JD009854, 2008.

Tiedtke, M.: A Comprehensive Mass Flux Scheme for Cumulus Parameterization in Large-Scale Models, Mon. Weather Rev., 117, 1779-1800, 1989.

Waters, J. W., Froidevaux, L., Harwood, R. S., Jarnot, R. F., Pickett, H. M., Read, W. G., Siegel, P. H., Cofield, R. E., Filipiak, M. J., Flower, D. A., Holden, J. R., Lau, G. K., Livesey, N. J., Manney, G. L., Pumphrey, H. C., Santee, M. L., Wu, D. L., Cuddy, D. T., Lay, R. R., Loo, M. S., Perun, V. S., Schwartz, M. J., Stek, P. C., Thurstans, R. P., Boyles, M. A., Chandra, K. M., Chavez, M. C., Chen, G. S., Chudasama, B. V., Dodge, R., Fuller, R. A., Girard, M. A., Jiang, J. H., Jiang, Y., Knosp, B. W., LaBelle, R. C., Lam, J. C., Lee, K. A., Miller, D., Oswald, J. E., Patel, N. C., Pukala,
D. M., Quintero, O., Scaff, D. M., Van Snyder, W., Tope, M. C., Wagner, P. A., and Walch, M. J.: The Earth Observing System Microwave Limb Sounder (EOS MLS) on the Aura Satellite, IEEE Trans. Geosci. Remote Sens., 44, 1075-1092, doi:10.1109/TGRS.2006.873771, 2006.

Worden, H. M., Logan, J. A., Worden, J. R., Beer, R., Bowman, K., Clough, S. A., Eldering, A., Fisher, B. M., Gunson, M. R., Herman, R. L., Kulawik, S. S., Lampel, M. C., Luo, M., Megretskaia, I. A., Osterman, G. B., and Shephard, M. W.: Comparisons of Tropospheric Emission Spectrometer (TES) ozone profiles to ozonesondes: Methods and initial results, J. Geophys. Res., 112, D03309, doi:10.1029/2006JD007258, 2007.

Zhang, L., Jacob, D. J., Liu, X., Logan, J. A., Chance, K., Eldering, A., and Bojkov, B. R.: Intercomparison methods for satellite measurements of atmospheric composition: application to tropospheric ozone from TES and OMI, Atmos. Chem. Phys., 10, 4725-4739, doi:10.5194/acp-10-4725-2010, 2010. 